\title{
А.Ф. СЛУДСКИЙ И КАРАДАГСКАЯ НАУЧНАЯ СТАНЦИЯ ИМЕНИ Т.И. ВЯЗЕМСКОГО В 1917 ГОДУ
}

\author{
Михаленок Д.к. \\ 2. Феодосия, Российская Федераиия, dmikhalenok@gmail.com
}

В 1917 г. в связи с известными политическими событиями в России, работа еще не окрепшей Карадагской научной станции им. Т.И. Вяземского была поставлена под угрозу. Тем не менее, силами малочисленных приезжих ученых, заведующего станцией А.Ф. Слудского и его помощника В.Н. Вучетича, проводились научные исследования. Вышел первый выпуск Трудов станции - этим станция заявила о себе в научном мире. Однако, в кризисных социальных условиях у А.Ф. Слудского возник вопрос выбора между Москвой и Карадагом. Ради сохранения станции он принимает решение остаться на Карадаге. В письмах А.Ф. Слудского к академику А.П. Павлову отражены мотивы такого непростого решения. Анализ архивных материалов раскрывает новые страницы в истории станции.

Ключевые слова: Карадагская научная станция им. Т.И. Вяземского, душеприказчики Т.И. Вяземского, Общество им. Х.С. Леденцова, события 1917 г., научные исследования на Карадаге, сохранение станции.

\section{Введение}

В 1910 г. геолог Александр Федорович Слудский (1884-1954) по совету своего учителя академика Алексея Петровича Павлова (1854-1929) приступил к изучению геологических особенностей Карадага. В это время он знакомится с доктором медицины Терентием Ивановичем Вяземским (1857-1914), который строит научную станцию в своем имении «Карадаг». С 1910 г. приоритет жизненных интересов А.Ф. Слудского постепенно перемещается из Москвы в Карадаг. После смерти Т.И. Вяземского в 1914 г. он продолжает его дело и становится заведующим станцией.

В письмах А.Ф. Слудского к А.П. Павлову и Марии Васильевне Павловой (18541938) мы видим подробности его жизни на Карадаге, удаленном от культурных центров. Видим, как приходится выполнять не только научную работу, но и целый спектр хозяйственных работ по станции. Помогает ему сотрудник станции, его помощник Виктор Николаевич Вучетич (1881-1945). Главное, что дает анализ писем - это картина душевной растерянности, когда в критической ситуации, вызванной событиями 1917 г., А.Ф. Слудский сделал очень сложный для себя выбор - остаться с семьей на Карадаге. В ином случае станция в буквальном смысле слова улетела бы в пропасть. Выбор А.Ф. Слудского поддержала его жена - Елена Николаевна Слудская (Антушева) (1890-1970).

Исторические события прошлого актуальны и в наше время, особенно в решении вопросов, направленных на организацию науки на Карадаге.

\section{Методика исследований}

Применена методика источниковедческого анализа с привлечением общенаучных методов исследований: аналитического, синтетического, исторического (ретроспективного) (Медушевская, 1976). Тексты архивных материалов передаются в современной орфографии, но с сохранением пунктуации.

Все даты указаны по старому (юлианскому) календарю. 


\section{Результаты и обсуждение}

\section{Знакомство с Карадагом}

А.Ф. Слудский - москвич, потомственный дворянин, родился в семье заслуженного профессора Московского университета Федора Алексеевича Слудского (1841-1897). В 1909 г. окончил естественное отделение физико-математического факультета Московского университета (рис. 1). Геолог, ученик академика А.П. Павлова, представитель «павловской» (московской) геологической школы (Павловская геологическая ..., 2004. С. 123-126).

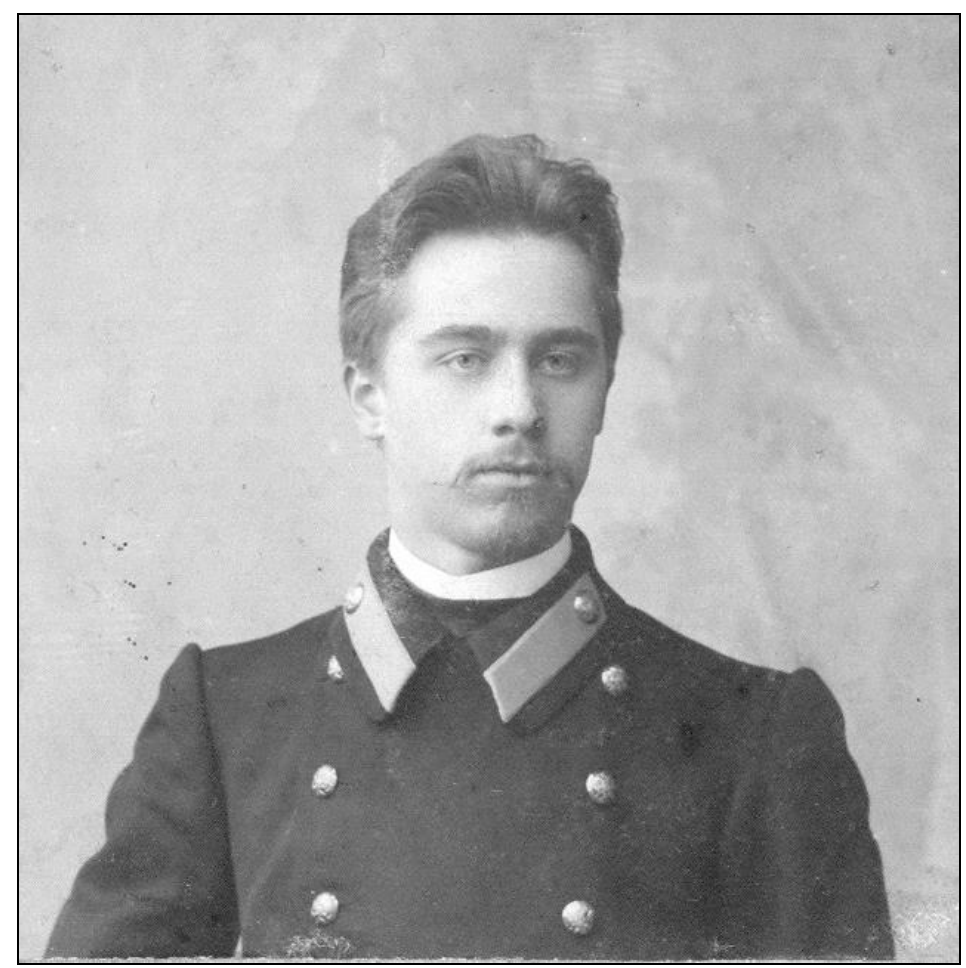

Рис. 1. А.Ф Слудский - студент Московского университета. Фотография 1907-1908 гг. Частный архив А.Ф. Слудского и его семьи в Симферополе.

После смерти Т.И. Вяземского в 1914 г., стал заведующим Карадагской научной станцией им. Т.И. Вяземского (далее: станция). Станция, еще при жизни Т.И. Вяземского была им пожертвована Обществу содействия успехам опытных наук и их практических применений им. Х.С. Леденцова, состоявшего при Московском университете и Московском техническом училище (далее: Общество).

Т.И. Вяземский увидел в А.Ф. Слудском продолжателя своего дела. Поэтому не случайно в своем завещательном распоряжении от 16 мая 1914 г. определил его одним из своих душеприказчиков. Вторым душеприказчиком стал известный общественный и политический деятель, член Государственной думы России Соломон Самуилович Крым (1867-1936). Он с большим уважением, любовью, пониманием относился к Т.И. Вяземскому и оставил о нем интересные воспоминания (С.С. Крым, 1917). Также предоставлял для строительства станции небольшие кредиты.

Показательно, что А.Ф. Слудскому Т.И. Вяземский в знак дружеских, доверительных отношений, завещал небольшой участок земли в две десятины. Так же Т.И. Вяземский ценил дружбу с известным физиком Алексеем Иосифовичем Бачинским (1877-1944), знакомство с которым состоялось на Карадаге летом 1912 г. Он рассказал Т.И. Вяземскому о деятельности Общества и «указал, что наилучшим способом дать деятельности станции прочную основу и надлежащее направление было бы - поставить ее под эгиду этого Общества [...]» 
(Бачинский, 1915. С. 29). Так же о станции и ее создателе он поведал своему учителю выдающемуся физику, товарищу председателя Общества Николаю Алексеевичу Умову (1846-1915) (Там же. С. 29). В дальнейшем, благодаря содействию Н.А. Умова, Т.И. Вяземский передал станцию Обществу. Т.И. Вяземский завещал А.И. Бачинскому участок земли в одну десятину. При этом он предоставил право А.Ф. Слудскому и А.И. Бачинскому самостоятельно выбрать эти участки (Архив КБС. Оп. 1. Д. 25. Л. 1).

А.Ф. Слудский выбрал участок на платообразной поверхности четвертичной пролювиальной террасы (плато) у подножья хребта Лобовой, а А.И. Бачинский - в небольшой долине у подножья вершины Шапка Мономаха (долина Бачинского) (рис. 2).

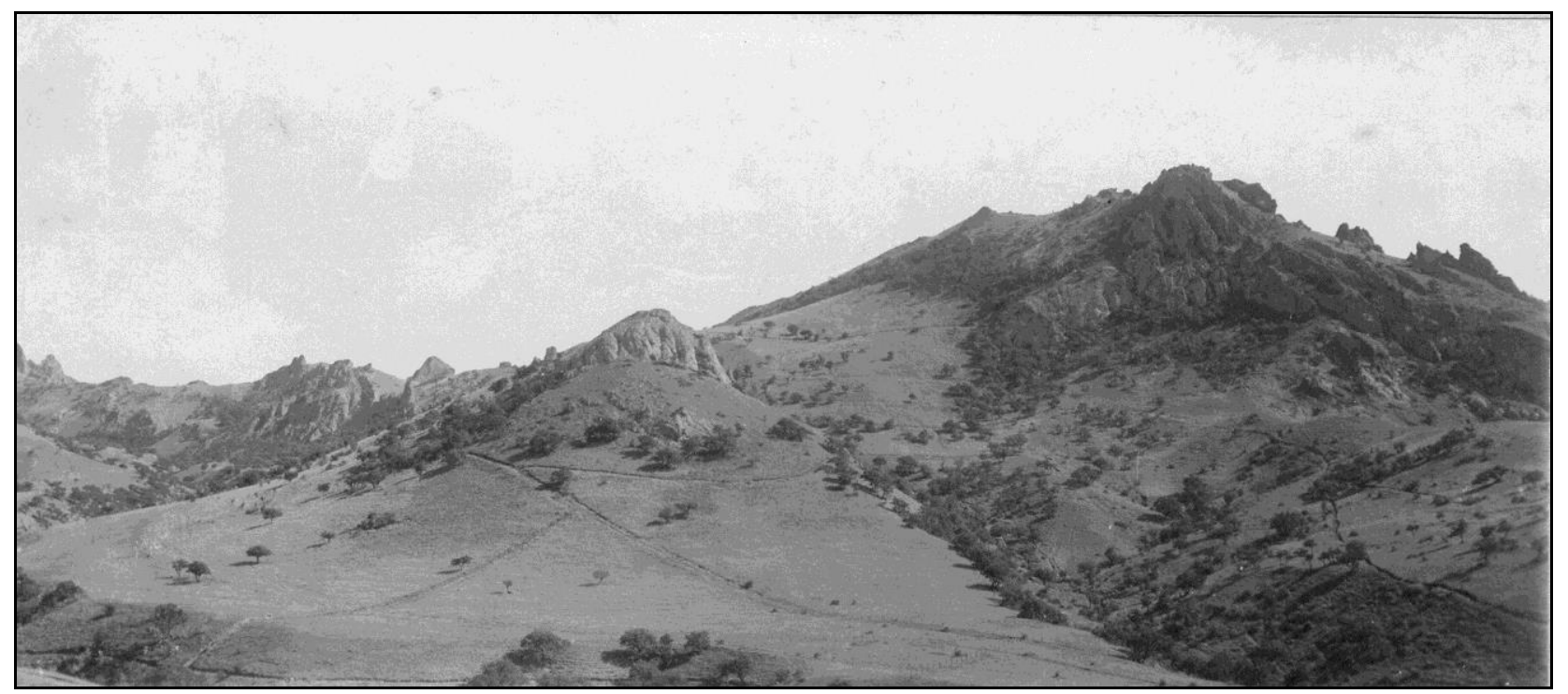

Рис. 2. Вершина Шапка Мономаха. Фотография начала XX века.

Частный архив А.Ф. Слудского и его семьи в Симферополе.

С.С. Крым, обладающий значительным капиталом и земельными участками в Крыму, в таком знаке внимания не нуждался. В связи с занятостью в политической деятельности, С.С. Крым в доверенности от 26 июня 1916 г., выданной феодосийским нотариусом А.И. Демерджи указал: «[...] уполномочиваю Вас принять в свое ведение и распоряжение имуществом умершего Т.И. Вяземского и поступить с ним согласно воли покойного Вяземского, выраженной в его духовном завещании. Всему законно учиненному я Вам верю, спорить и прекословить не буду. Доверенность эта принадлежит потомственному дворянину Александру Федоровичу Слудскому» (Архив КБС. Оп. 1. Д. 25. Л. 4). Впрочем, в решениях сложных вопросов, касающихся движимого и недвижимого имущества Т.И. Вяземского, С.С. Крым оказывал А.Ф. Слудскому действенную помощь.

Вторую доверенность на управление имением и станцией А.Ф. Слудский получил от Общества 7 июля 1915 г. Она очень подробна и касается вопросов, связанных с хозяйственной, правовой, научной деятельностью станции. В тексте доверенности, в частности, указано: «Совет Общества [...] уполномочивает Вас заведовать и управлять принадлежащим означенному Обществу недвижимым имением, [...] в урочище Карадаг Кабурга, а так же биологической станцией, находящейся в означенном имении, для чего доверяет Вам отдавать означенное имение и находящиеся в нем помещения и постройки в аренду и наем [...] страховать строения и движимость от огня, [...] быть представителем Общества в сношениях с полицейскими и административными властями, а также ходатайствовать по делам означенного имения во всех судебных местах [...] Всему, что по сей доверенности законно сделаете, Общество Вам верит и спорить не будет» (ЦИАМ. Ф. 224. Оп. 1. Д. 66. Л. 117, 117 об.). 
Общество в мае 1915 г. посылает на Карадаг зоолога В.Н. Вучетича в качестве помощника заведующего станцией (Михаленок, Лапченко, 2014. С. 12). Станция работала с 1 мая по 1 октября. В этот период на станции находился ее заведующий - А.Ф. Слудский, который затем уезжал в Москву, где работал в качестве хранителя Геологического кабинета Московского университета. В.Н. Вучетич работал на станции круглогодично. Для организации деятельности станции в Обществе была создана Попечительная комиссия в следующем составе: председатель - академик, геолог А.П. Павлов, члены комиссии: товарищ председателя (с 1915 г.) Общества, физико-химик Иван Алексеевич Каблуков (1857-1942) и член Общества микробиолог и физиолог растений Николай Николаевич Худяков (1866-1927). А.П. Павлов не только содействовал А.Ф. Слудскому в его ответственной работе на Карадаге, но и защищал интересы станции в Обществе. После избрания А.П. Павлова 14 апреля 1915 г. председателем Попечительной комиссии, Общество выразило ему «[...] глубокую благодарность за всю [...] предшествующую деятельность по разработке положения, правил, инструкции и вообще организации [...] станции» (ЦИАМ, Ф. 224. Оп.1. Д. 66. Л. 47).

При каких обстоятельствах А.Ф. Слудский познакомился с Т.И. Вяземским? Когда на всю жизнь возникла любовь и привязанность к Карадагу?

Летом и осенью 1910 г. произошли события, навсегда связавшие А.Ф. Слудского с Карадагам: они будто судьбой были предопределены. Об этих событиях жена А.Ф. Слудского - Е.Н. Слудская (рис. 3) оставила интересные заметки, относящиеся к середине 1960-х гг. Они хранятся в частном архиве А.Ф.Слудского и его семьи в Симферополе (далее: ЧАСС) - у внучки А.Ф. Слудского Елены Абрамовны Оноприенко и ее мужа Алексея Николаевича Оноприенко. Рукописные записи хранятся в отдельной тетради в линейку с надписью от руки: «Заметки о семье Слудских» (далее: Заметки). Для удобства пользования документом нами проведена условная нумерация листов (без включения цифр в документ). Из текста записей узнаем, что впервые с Карадагом А.Ф. и Е.Н. Слудские познакомились летом 1910 г., когда по рекомендации А.П. Павлова приехали в Коктебель. Месяц жили в доме поэта Максимилиана Александровича Волошина (1877-1932) и подружились с ним. Тогда горы интересовали мало: «[...] больше увлекались морем, купаньем, собиранием замечательных камешков на берегу [...] » (ЧАСС. Заметки. Л. 6).

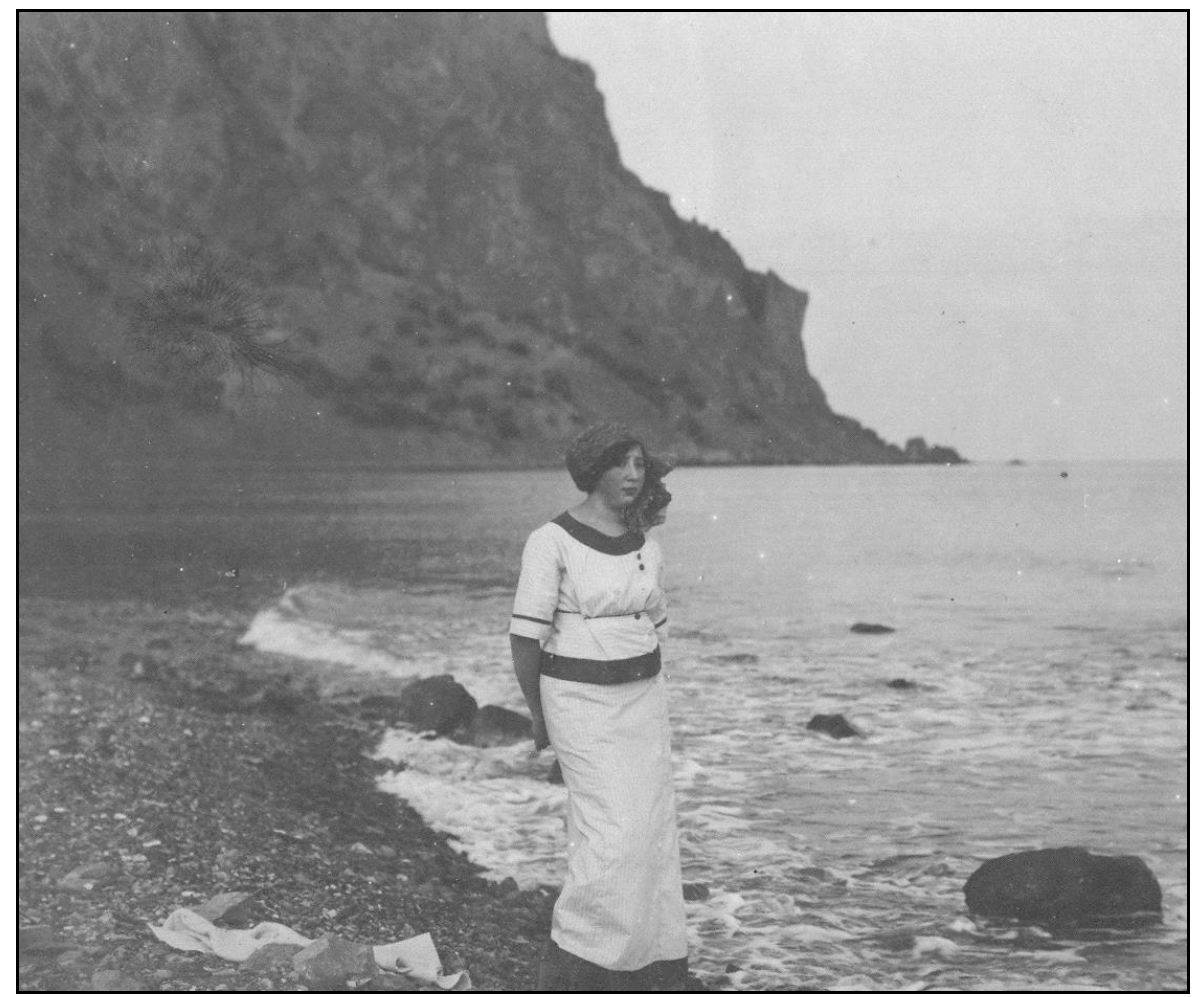

Рис. 3. Е.Н. Слудская на берегу Карадагской бухты. Фотография 1915-1917 гг. Частный архив А.Ф. Слудского и его семьи в Симферополе. 
После отдыха, с сожалением покинули пустынный, прекрасный Коктебель и уехали в Москву.

Этим же летом в Коктебеле отдыхали А.П. Павлов и его жена М.В. Павлова. Они познакомились с Т.И. Вяземским в его имении «Карадаг» при весьма печальном событии во время прогулки по Карадагу на лошадях М.В. Павлова повредила ключицу. «В одном месте, - отметила Е.Н. Слудская, - лошадь споткнулась о камни и очень неудачно прижала М[арию] В[асильевну] к дереву с такой силой, что у М[арии] В[асильевны] повредилась ключица - переломилась с сильной болью» (Там же. Л. 3).

Проводник указал на белые здания имения Т.И. Вяземского (рис. 4) «[...] и объяснил, что там живет очень хороший доктор, который может помочь» (Там же. Л. 3, 4). С трудом добрались к доктору Т.И. Вяземскому: «Он принял их очень радушно, - пишет Е.Н. Слудская, - оказал М[арии] В[асильевне] нужную ей медиц[инскую] помощь, и отпустил их только тогда, когда миновала необходимость в его лечении» (Там же. Л. 5).

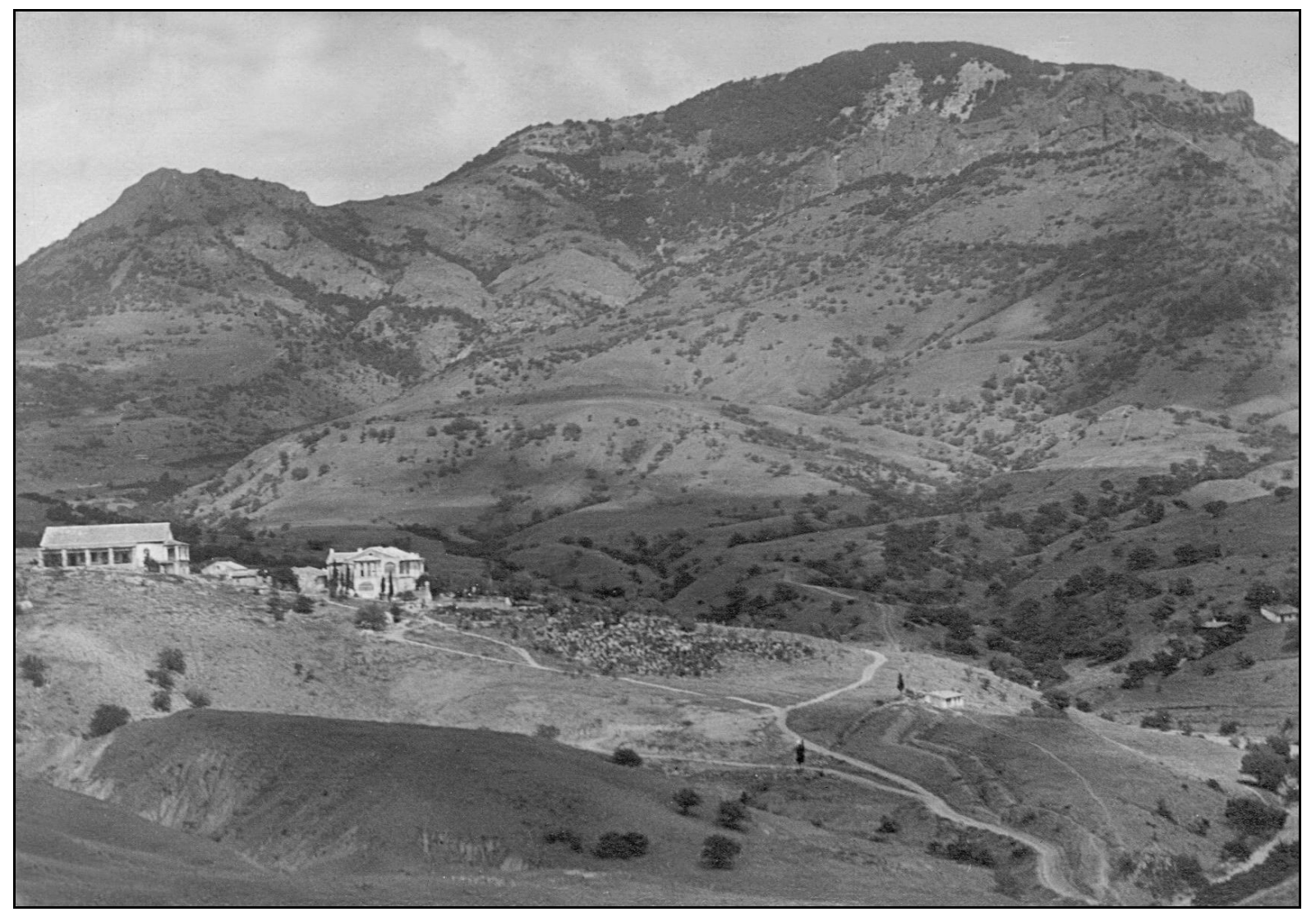

Рис. 4. Имение Т.И. Вяземского. Фотография начала XX века (предоставлена канд. биол. наук В.Г. Шатко, г. Москва).

В Москве, в сентябре этого же года, А.П. Павлов рассказал А.Ф. Слудскому о Т.И. Вяземском и его станции, так же об уникальных геологических особенностях древнего вулкана и предложил ему заняться геологическим изучением Карадага. Для этого он командировал А.Ф. Слудского на Карадаг, к Т.И. Вяземскому. А.Ф. Слудский и Е.Н. Слудская вновь приехали в Крым в октябре месяце. Они застали отъезжающего в Москву Т.И. Вяземского. «Он предоставил в наше распоряжение весь дом, все хозяйство на любое время, сторожа Григория, стряпуху Христю, несколько коров, правда в очень плохом состоянии [...]. - Пишет Е.Н. Слудская. - А[лександр] Ф[едорович] сразу же начал ежедневные экскурсии в горы, с молотком и рюкзаком на спине, и чем дальше, тем больше увлекаясь и очаровываясь и как геолог, и как страстный любитель природы» (Там же. Л. 7).

Теплая осень, ясные солнечные дни позволили А.Ф. и Е.Н. Слудским прожить в имении Т.И. Вяземского до конца декабря. Уже после отъезда в Москву в последних числах 
декабря «[...] началась зима с морозами, метелями, сильными снегопадами - так нам сообщили, - отметила Е.Н. Слудская. - Во́-время мы уехали. Так началась наша крепкая дружба с Карадагом, глубокая привязанность и любовь к этому чудесному уголку Крыма, длящаяся уже третье поколение: мы, наши дети и внуки» (Там же. Л. 8).

В записках Е.Н. Слудской много радости, искренних чувств, любви к замечательному месту - Карадагу, ставшим для А.Ф. и Е.Н. Слудских малой родиной, вторым, а быть может и основным домом в жизни. Они покинули Москву, ее бурную культурную и светскую жизнь, оставили привычный, комфортный уклад жизни.

Е.Н. Слудская пишет: «[...] прочно вошел в нашу с А[лександром] Ф[едоровичем] жизнь Крым и, в частности, Карадаг, в жизнь людей, коренных москвичей, бывших крепко привязанных к московской жизни и ее окружающей природе окрестностей, к родственникам, друзьям, многим знакомым. Оторваться от жизни культурной с театрами, концертами, выставками и т[ому] п[одобному], оторваться от научного центра - университета, с которым А[лександр ] [Федорович] был тесно связан и работал в нем, и с горячо любимым и любящим его патроном проф[ессором]-геологом Алексеем Петровичем Павловым [рис. 5], (впоследствии академиком), и расстаться с университетскими товарищами и т[ак] д[алее]. Оторваться от всех этих благ, чтобы поселиться на долгие годы в пустынном, почти изолированном от жилья людей, но прекрасном, изумительно красивом, своеобразном уголке Восточного Крыма - Карадаге» (Там же. Л. 3 - 4).

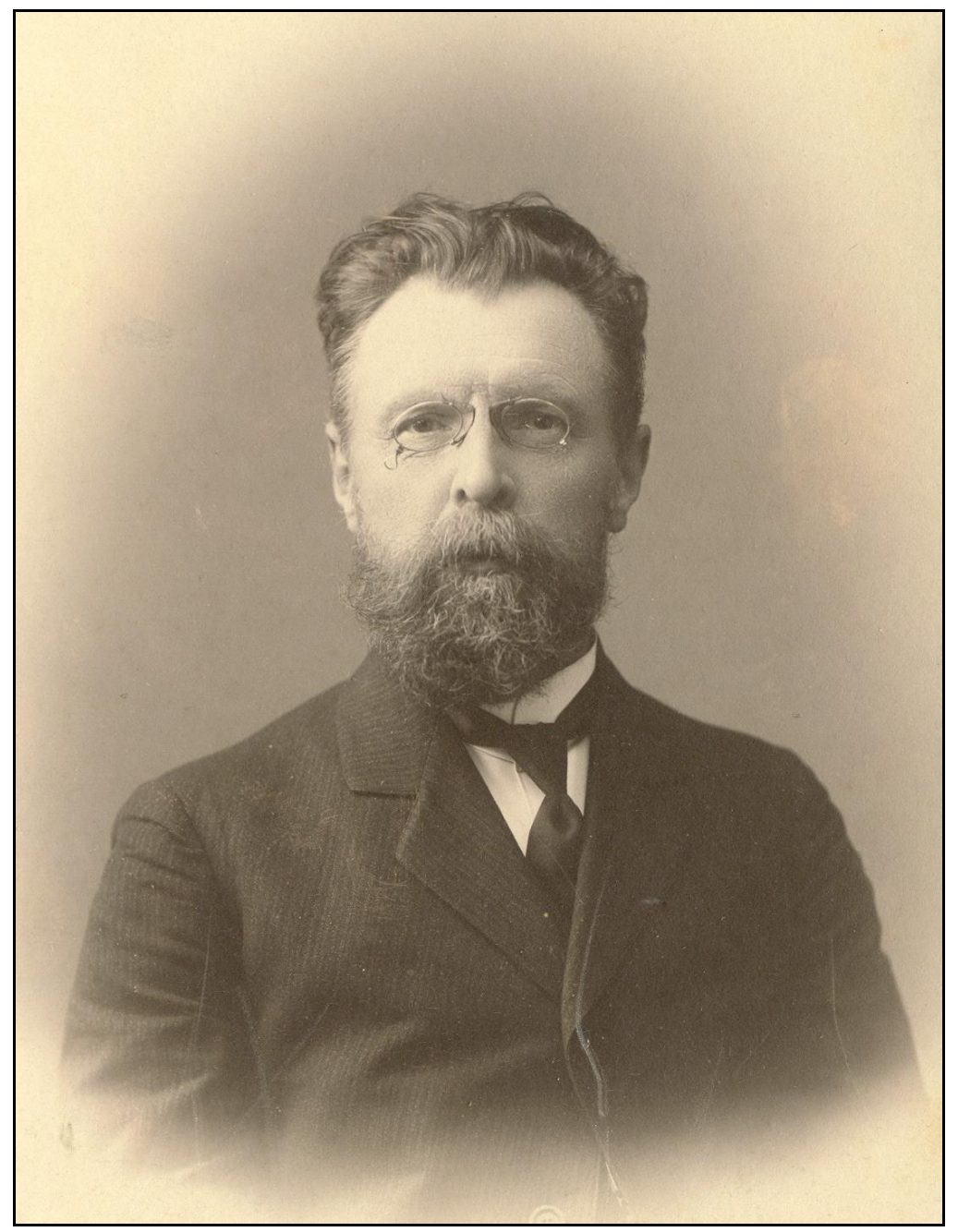

Рис. 5. А.П. Павлов. Фотография 1910-х гг. Частный архив А.Ф. Слудского и его семьи в Симферополе. 
Не ошибемся в том, что великая любовь к одному из самых замечательных мест на земле привела А.Ф. Слудского и Е.Н. Слудскую на Карадаг. Послушаем поэтические мотивы на тему живописных карадагских осенних красок в стихотворении А.Ф. Слудского «Осенние дни», написанного, предположительно, в 1919-1920 гг. Машинописный вариант стихотворения находится среди листов тетради в линейку с рукописными стихотворениями. Тетрадь условно названа нами Тетрадью стихов А.Ф. Слудского.

«В эти дни так чарует восторженный взгляд

Горных далей прозрачный воздушный наряд.

Алый свет озаряет каскадом огней

И луга, и леса и утесы камней.

На горах пятна крови осенней листвы

Золотыми огнями в узор сплетены.

Изумруды, рубины, лучистый сапфир

Диадемой священной одели кумир.

В эти дни среди моря царит тишина

И волна, не дыша, к берегам прилегла.

Перламутр и опал под искусной рукой

Всколыхнули гимн красок для дали морской.

В эти дни первозданная радость живет

В зачарованной ткани небесных высот,

И невидимой нитью в лазурь вплетена

С бесконечным сияньем сроднилась душа».

(ЧАСС. Тетрадь стихов А.Ф. Слудского. Машинопись с незначительными авторскими исправлениями от руки. Публикуется впервые).

\section{О событиях в 1917 году}

К 1917 г. по станции оставались неуплаченные Т.И. Вяземским долги, что могло привести к ликвидации имущества станции в счет покрытия этих долгов. Чтобы этого не случилось, Общество время от времени оплачивало такие долги. Например, еще в конце декабря 1915 г. Общество уведомило А.Ф. Слудского о том, что оказывает содействие душеприказчикам «[...] в уплате части долга по имуществу ассигнованием до 8000 руб[лей], каковая сумма подлежит возврату Обществу из средств по имению Т.И. Вяземского» (ЦИАМ. Ф. 224. Оп. 1. Д. 66. Л. 130). Заметим, что этот долг был оплачен С.С. Крыму. Кроме того, оставался долг в размере 16 тысяч рублей для оплаты так же С.С. Крыму. Вероятно, С.С. Крым оплатил за Т.И. Вяземского чужие долги. В данном случае сработали оправданные, прагматические механизмы в денежных взаимоотношениях между душеприказчиками и Обществом.

Порой возникали спорные вопросы по передаче земли Обществу. Председатель Общества Семен Андреевич Федоров (1860-1934) и секретарь Общества Николай Францевич Чарновский (1868-1938), весьма деликатно обращаются к душеприказчикам с предложениями по решению земельных вопросов: «[...] просить г.г. [господ] душеприказчиков принять все зависящие меры к выяснению и точному установлению всех земельных отношений по завещанному владению, и установлению точных и бесспорных границ владений, подлежащих передаче Обществу, а в отношении тех участков, которые поступают в распоряжение душеприказчиков на правах давности, - вступить во владение, с тем, чтобы в течение 1916 года все указанные формальности по владению были закончены и Общество могло бы вступить во владение со всей полнотой прав собственника и без каких либо дальнейших споров и обязательств» (ЦИАМ. Ф. 224. Оп. 1. Д. 66. Л. 130, 130 об.). 
Для решения различных хозяйственных вопросов, на Карадаг должны были приехать члены Общества. Однако, ни в 1916 г., ни в 1917 г. этого не случилось. Как увидим из писем А.Ф. Слудского к А.П. Павлову на Карадаг смог приехать в августе 1917 г. только Н.Ф. Чарновский.

В 1917 г. оставался последний платеж С.С. Крыму на 8000 рублей. В связи с чем, 30 января 1917 г. А.Ф. Слудский обратился в Общество с предложением оплатить долг: «[...] уплата окончательно устранит необходимость ликвидации имущества душеприказчиками» (ЦИАМ. Ф. 224. Оп. 1. Д. 85. Л. 30). Нам пока не удалось проследить судьбу этого долга.

Уезжая весной 1917 г. в Крым, А.Ф. Слудский, в частности, планировал решить многие формальности и обязательства, возникшие между Обществом и душеприказчиками. Летом 1917 г. истекали три года, после которых, согласно завещанию Т.И. Вяземского, душеприказчики должны были передать все имущество «[...] Обществу [...] в полное и неограниченное заведывание и распоряжение, при чем, - указал Т.И. Вяземский в завещании, - я выражаю пожелание, чтобы все завещаемое мною Обществу движимое и недвижимое имущество служило целям и нуждам научной станции на Карадаге» (Архив КБС. Оп. 1. Д. 25. Л. 2). По сути, Общество уже владело имуществом Т.И. Вяземского, необходимо было соблюсти только юридические формальности.

До отъезда А.Ф. Слудского на Карадаг, члены Общества активно обсуждали различные вопросы по организации хозяйственного функционирования и научной деятельности станции. Возникли разногласия, поскольку хозяйство имения включало в себя здания санатория Т.И. Вяземского (пансион), в которых могли останавливаться прибывшие на Карадаг ученые, небольшое подсобное хозяйство, буфет, виноградники и др. хозяйственные объекты. Главным научным объектом для Общества были два рядом расположенных здания: станции и здание для сотрудников станции и, отчасти, для приезжих. Для обслуживания имения и станции нужны были средства. Этот непростой вопрос обсуждали на заседании Попечительной комиссии станции 13 февраля 1917 г. в помещении Общества в доме № 47 на Садово-Земляном валу. Член Попечительной комиссии, Н.Н. Худяков не смог присутствовать на совещании, но прислал свое письмо, которое и явилось объектом подробного обсуждения. Н.Н. Худяков был против того, чтобы станция и имение функционировали как одно целое. Суть его позиции заключалась в следующем: «По моему мнению, - указал в письме Н.Н. Худяков, - единственно, что можно сделать с имением Карадаг - это постараться сдать в аренду как землю отдельными участками, так и пансион с буфетом и обратить все внимание не на организацию имения, а на создание научной станции» (ЦИАМ. Ф. 224. Оп. 1. Д. 85. Л. 32, 33).

Противоположное мнение на заседании высказал А.П. Павлов. Он хорошо знал, что жизнь на Карадаге далека от комфорта и полагал, что, по крайней мере, для удовлетворительного проживания, имение и станция должны быть одним целым. Он, в частности, указал, что «[...] особые условия жизни научных работников на Карадагской научной станции (удаленность от культурных центров) делают необходимым организацию со стороны Общества пансиона с буфетом, так как сдача его арендатору может поставить приехавших на станцию в такое положение, при котором правильная научная деятельность станет маловозможной» (Там же. Л. 35).

Объективную ситуацию на Карадаге в полной мере знал А. Ф. Слудский, который присоединился к мнению А.П. Павлова и разъяснил присутствующим: «[...] сложное хозяйство имения Т.И. Вяземского на Карадаге столь тесно связанное с хозяйством Карадагской научной станции нельзя передавать во владение разных лиц - или Общество само должно этим заняться или передать все это дело одному лицу, которому оно доверяет» (Там же. Л. 35).

Оценив различные мнения, председатель Общества С.А. Федоров предложил летом 1917 г. осмотреть станцию и имение специальной комиссией Общества. Так же Общество пригласило для заведования хозяйством имения Павла Прокофьевича Уварова (1869-1927?). 
Личность этого человека еще предстоит уточнить. Предположительно, речь идет о преподавателе одной из московских гимназий, автора учебных книг по географии России.

Очень хорошо отозвался об П.П. Уварове А.П. Павлов, охарактеризовав его как «[...] драгоценного работника, опытного и знающего человека, за которого можно ручаться» (Там же. Л. 35 об.).

По поводу П.П. Уварова, А.Ф. Слудский сказал: «[...] душеприказчики Т.И. Вяземского могут пригласить г[осподина] Уварова в Карадагскую станцию на лето 1917 года, чтобы он мог познакомиться с делом до передачи душеприказчиками Обществу Леденцова владений Т.И. Вяземского (в августе 1917 года)» (Там же. Л. 35 об.).

Член Совета Общества, Константин Константинович Нотгафт заметил, что у Общества различные отношения к станции и к имению. Он подчеркнул: «Когда имение перейдет во владение Общества, то должно быть самостоятельное хозяйственное управление и особая статья расходов и доходов с имения». Он так же отметил, что доходы с имения должны идти как на оплату расходов по нему, так и на развитие станции (Там же. Л. 35 об.).

Заметим, что присутствующим на заседании Общества было понятно, что доходы с имения не могут покрыть все расходы на его содержание и на развитие станции - в данном случае на самоокупаемость имения и станции рассчитывать не приходилось. Поэтому, постановили: «Посетить Карадагскую научную станцию летом 1917 года Президиумом и членам Общества. Желательно участие С.С. Крыма». Кроме того: «Обратиться к правительству с ходатайством о назначении специальной субсидии на нужды станции и просить А.Ф. Слудского составить соответствующую докладную записку к правительству, которую следует обсудить в заседании Попечительной комиссии, если можно совместно с Бюро Общества» (Там же. Л. 35 об.).

Докладная записка А.Ф. Слудского по данному вопросу не обнаружена.

В марте 1917 г. Общество заранее, более чем за месяц до открытия станции, командирует А.Ф. Слудского в Таврическую губернию по делам станции. В выданном 20 марта удостоверении читаем: «Общество [...] покорнейше просит все учреждения и лица оказывать возможное содействие Александру Федоровичу Слудскому при выполнении им возложенных на него обязательств» (Там же. Л. 36). Вероятно, такая предупредительная ситуация была связана как с графиком заседаний Общества, так и необходимостью дать время А.Ф. Слудскому спокойно подготовиться к отъезду и уладить все формальности в Московском университете, где к тому времени он занимал должность старшего ассистента Геологического кабинета.

Готовясь к отъезду, А.Ф. Слудский подает несколько ходатайств в Общество по поводу приобретения для станции пишущей машины «Смис Премьер» - пожалуй лучшей для того времени. Так, в ходатайстве от 22 марта 1917 г. он отметил: «[...] полная стоимость машины с запасом принадлежностей и доставкой в Отузы будет около 570 рублей» (Там же. Л. 37 об.).

Надо полагать, что Общество не отказало А.Ф. Слудскому в приобретении важного и необходимого в работе станции инструмента. Определенное подтверждение находим в том, что три письма, адресованные А.П. Павлову из Карадага, напечатаны на пишущей машине, а одно написано А.Ф. Слудским 7 августа 1917 г. в Феодосии от руки.

В конце апреля А.Ф. Слудский с женой Еленой Николаевной и семилетним сыном Евгением от первого брака А.Ф. Слудского, покинули родовое гнездо семьи Слудских собственный дом на Покровке № 11 и уехали на Карадаг, не ведая, что им предстоит пробыть там безвыездно пять сложнейших лет. Укажем, что А.Ф. Слудский первым браком был женат на родной сестре Елены Николаевны - Ольге Николаевне Антушевой (18881980). Здесь имеет место сложная история любви, которую мы склонны не обсуждать, а констатировать. Евгений Александрович Слудский (1910-1991) оставил интересные воспоминания о Карадаге (Слудский, 2004-2005), охватывающие период 1917-1926 гг. При этом пять лет - на протяжении 1917-1922 гг. он вместе с отцом находился на Карадаге. При 
чтении воспоминаний, следует учитывать, что это детские и юношеские впечатления, в которых отдельные симпатии и антипатии к событиям и людям, не всегда могут быть объективны и точны.

Что происходило на Карадаге в 1917 г., почему этот год связал судьбу А.Ф. Слудского с судьбой станции? Ответы находим, в основном, в письмах А.Ф. Слудского, написанных на Карадаге к А.П. Павлову и М.В. Павловой. В них видим не только мотивацию столь непростого для А.Ф. Слудского решения остаться на Карадаге, но и много деталей, характеризующих быт и научную деятельность, неуверенность отправителя писем в своем положении и беспокойство за судьбу станции. Письма хранятся в Архиве Российской академии наук (далее: Архив РАН). Сохранилось пять писем А.Ф. Слудского, четыре из них адресованы к А.П. Павлову и одно адресовано М.В. Павловой (рис. 6). Так же представляет интерес письмо, отправленное из Карадага Е.Н. Слудской М.В. Павловой (письмо хранится в Архиве РАН). Весьма краткий анализ писем А.Ф. Слудского к А.П. Павлову опубликован в материалах Международной научной конференции, проходившей в Москве 4-7 июня 2013 г. (Михаленок, 2013). Ниже подробно проанализируем тексты писем и рассмотрим другие архивные материалы и литературные источники, соприкасающиеся с их содержанием.

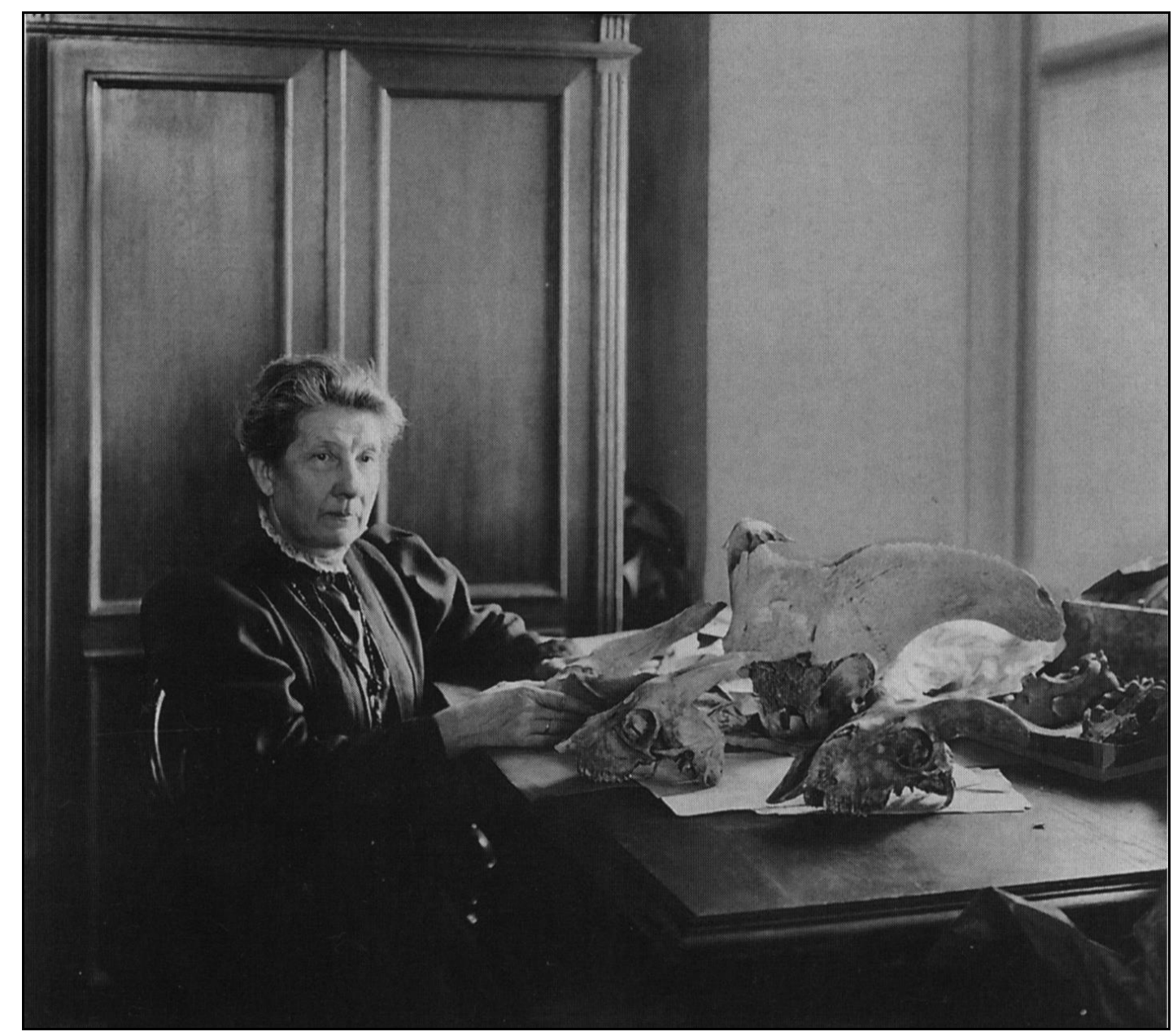

Рис. 6. М.В. Павлова за рабочим столом. Фотография 1920-х гг. (Павловская геологическая..., 2004. Ил. [6]).

Начнем с письма Е.Н. Слудской, отправленного 5 мая, вскоре после приезда на Карадаг. Она пишет о разных сторонах «житья-бытья». Прежде всего, обращает внимание на благодатную атмосферу Карадага, тишину, мир, спокойствие. «Особенно это чувствуется, подчеркивает Е.Н. Слудская, - после ужасной зимы в Москве». Сообщает, что доехали «идеально» (Архив РАН. Ф. 311. Оп. 2. Д. 3. Л. 1). Радуется наличию в Крыму продуктов 
питания: «В Феодосии нас поразил и великолепный белый хлеб в изобилии, и печенье, и мука. Правда теперь начинают и здесь ограничивать понемногу выпечку белого хлеба, но все же пока можно получать все без карточек и без хвостов [очередей]. Только с сахаром плохо: в Отузах нам дают по $1^{1 / 2}$ ф[унта] на человека в месяц» (Там же. Л. 1, 1 об.). Пишет о переменах в саду, сообщает, что В.Н. Вучетич «насадил массу цветов и деревьев», замечает, что «сегодня расцвела первая роза». Пишет, что В.Н. Вучетич «совершенно с ног сбился», поскольку «[...] помимо работы на станции, состоит Отузским комиссаром, что отнимает много и сил и времени» (Там же. Л. 1-2). Об А.Ф. Слудском пишет, что он «[...] исполняет обязанности и монтера, и слесаря и т[ому] п[одобное]» (Там же. Л. 2). Сообщает о своем племяннике и сыне А.Ф. Слудского Е.А. Слудском: «Жене очень понравилось на Карадаге, бегает, прыгает, даже уже загорел, восторгается и морем, и горами, и камешками» (Там же. Л. 2). В последнюю очередь говорит о себе: «Я чувствую себя здесь несравненно лучше, чем в Москве. Дышится здесь так легко после всей московской сутолоки» (Там же. Л. 2, 2 об.). Как видим, к Карадагу Е.Н. Слудская относится с большой любовью. Пишет, что надеется видеть А.П. Павлова и М.В. Павлову на Карадаге, «[...] тем более, что и с питанием пока обстоит неплохо; Павел Прокоф[ьевич] Уваров старается по мере сил и возможности питать нас, и пока мы сыты и довольны. Дай Бог, чтобы и дальше шло так» (Там же. Л. 2 об.).

Как увидим из писем А.Ф. Слудского, работа у П.П. Уварова в последующие месяцы не заладилась. К сожалению, П.П. Уваров не оправдал надежд А.П. Павлова и Общества - не смог организовать хозяйственную часть работ на Карадаге. Этим довелось заниматься А.Ф. Слудскому.

В завершении письма шлет свой «нижайший поклон Алексею Петровичу» и шлет поклоны от А.Ф. Слудского. Письмо проникнуто уважением и любовью к М.В. Павловой и А.П. Павлову. «Любящая Вас Ел[ена] Антуш[ева]» - так подписала свое письмо Е.Н. Слудская (Там же. Л. 2 об.).

Свое первое письмо из Карадага от 22 мая А.Ф.Слудский так же адресует М.В. Павловой. Обращаясь к «Дорогой Марии Васильевне» в ожидании ее приезда на Карадаг, А.Ф. Слудский очень искренно и с любовью к адресату пересылает небольшой, увлекательный рассказ - «[...] частичку Карадага - маленький обрывок жизни и интересов нынешнего сезона».

Сведения об этом «обрывке жизни» повествующие о становлении работ и устройстве жизни на станции, не утратили своего интереса и сегодня.

«Жить на Карадаге можно, - пишет А.Ф. Слудский, - и, быть может, лучше, чем гделибо в другом месте России: здесь тихо, спокойно и нет голода. Газеты приходят очень неаккуратно, и поэтому приходится читать о давно прошедших событиях: читаешь не газету, а историческую летопись, и это обстоятельство создает более спокойное отношение к событиям» (Архив РАН. Ф. 311. Оп. 2. Д. 227. Л. 1, 1 об.).

События были достаточно тревожными. Напомним о Февральской революции в Петрограде, отречении Николая II от престола, образовании Временного правительства, продолжении Первой мировой войны...

«А дела, - пишет А.Ф. Слудский, - несмотря ни на что, не стоят». Он отметил, что небольшая лодка «Ундина» «[...] служит верой и правдой (хотя и протекает немножко). Сегодня работали на ней около Коз, мечтаем на днях добраться до Меганома. Это дерзкая мечта: «Ундина» так мала, что не выносит ветра, и мы выезжаем теперь в 6 утра, что-бы успеть поработать до наступления бриза, который обычно в 9-10 утра загоняет нас домой» (Там же. Л. 1 об.).

К сожалению, «Ундину» украли «году в 1919-1920-м», - вспоминал Е.А. Слудский (Слудский, 2004-2005. С. 44).

А.Ф. Слудский увлеченно рассказал М.В. Павловой о том, как лодка попала в стаю дельфинов, которые не боялись шума мотора и приняли лодку «за своего собрата». Кратко 
касается предварительных результатов морских исследований: «Результаты работ уже есть кое-какие: значительно расширились наши сведения об окрестностях станции и произведены исключительно удачные и интересные наблюдения над течениями». Вышеизложенное начало письма А.Ф. Слудский характеризует как «лицевую сторону». Замечает: «[...] чтобы достичь ее - сколько приходится испытать обратной стороны! Впрочем - сколько этих обратных сторон!» (Архив РАН. Ф. 311. Оп. 2. Д. 227. Л. 4).

Последние касаются сложных условий жизни на Карадаге, определенной оторванности его от культурного мира.

В связи с чем, А.Ф. Слудский очень образно сказал: «Мне кажется иногда, что мы Робинзоны, заброшенные на необитаемый остров. Все здесь приходится начинать с самого начала» (Там же. Л. 4, 4 об.) (рис. 7).

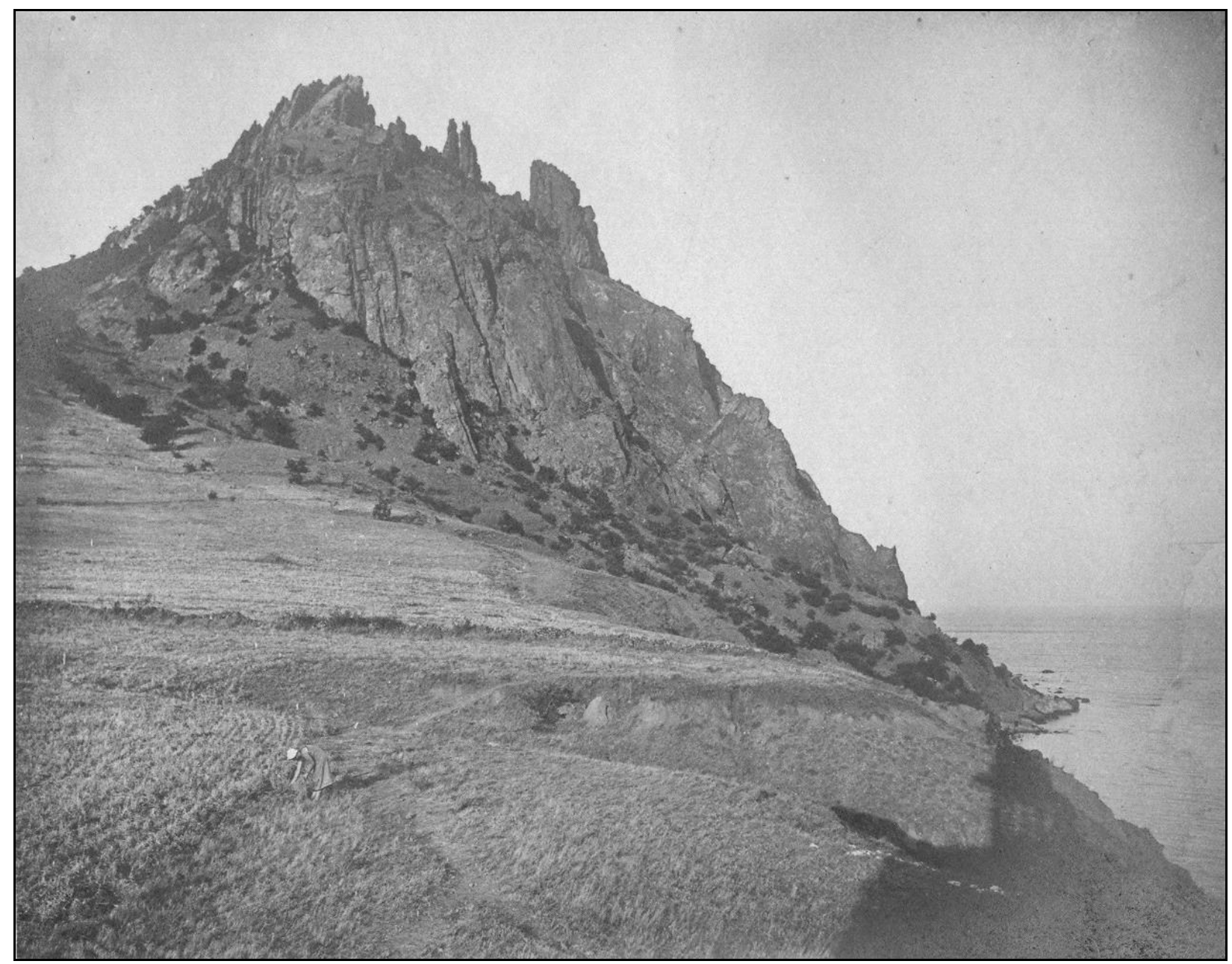

Рис. 7. Береговая часть «острова» Карадаг. Фотография А.Ф. Слудского, 1915-1917 гг. Публикуется впервые. Частный архив А.Ф. Слудского и его семьи в Симферополе.

Приводит пример, как на земле, «которая едва поддается стальному лому», В.Н. Вучетич чудесным образом создает тропический сад и выращивает розы (Там же. Л. 4 об.).

В начале 1920-х гг. в саду уже были небольшие деревья (рис. 8). Об этом саде Е.А. Слудский вспоминал: «Там у него [В.Н. Вучетича] росли молодые яблоньки, абрикосы, персики, груши. У каждого деревца выструганный, окрашенный желтой краской колышек в полметра, на нем вертикально написано название сорта, русскими и латинскими буквами» (Слудский, 2004-2005. С. 39-40). 


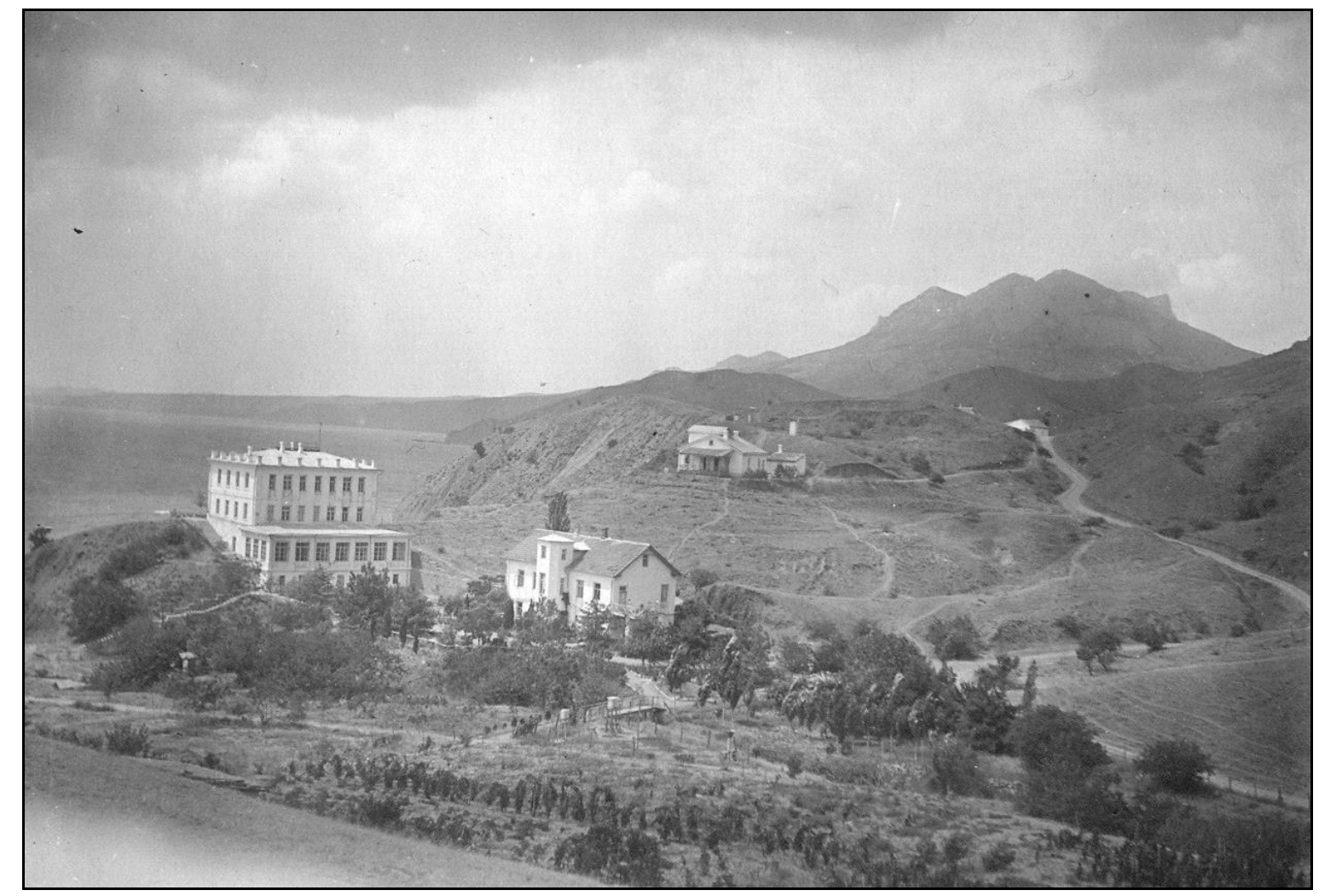

Рис. 8. Общий вид Карадагской научной станции им. Т.И. Вяземского. Фотография 1920-х гг. На переднем плане фруктовый сад В.Н. Вучетича. Частный архив А.Ф. Слудского и его семьи в Симферополе.

В письме А.Ф. Слудский отметил, что розы были выписаны В.Н. Вучетичем из Одессы в марте, за свой счет, в качестве дара станции и были получены только в мае, без земли, «в виде сухих ломких прутьев». Можно представить отчаяние В.Н. Вучетича! «Но совершилось чудо, - продолжает рассказ А.Ф. Слудский, - розы ожили вопреки законам и здравому смыслу. Но вряд-ли кто-нибудь представит себе сколько труда и любви было положено в дело воскрешения роз: дай Бог, что-бы за больным человеком так ухаживали, как ухаживал В[иктор] Н[иколаевич] за больными розами!» Этот пример самоотверженного труда, по мнению А.Ф. Слудского, характерен для каждого дела, предпринимаемого на станции: «Вот при таком отношении к делу, несмотря на все невзгоды и тягости, станция живет и движется» (Архив РАН. Ф. 311. Оп. 2. Д. 227. Л. 4 об.-2 об.).

«Новый карадажец» П.П. Уваров, посланный на Карадаг Обществом, не мог преодолеть трудностей для решения ряда хозяйственных вопросов на станции. В отличие от В.Н. Вучетича и самого А.Ф. Слудского, это был человек «иного типа».

А.Ф. Слудский пишет о нем: «У него маленькие дела превращаются в большие и маленькое затруднение - в непреодолимое препятствие». А.Ф. Слудский не мог понять в чем причина происходящего, поскольку «[...] все его хорошие стороны - добросовестность, основательность - на лицо». Почему возникла такая ситуация с умным, честным, добросовестным, образованным человеком? В письме к М.В. Павловой А.Ф. Слудский дает своеобразный, но очень точный ответ: «[...] не хватает какого-то винтика, который необходим, и в результате он затрачивает много энергии, сильно устает, а дело идет далеко не гладко и, боюсь, что ничего в конце концов не выйдет» (Там же. Л. 2, 2 об.).

Так и случилось, П.П. Уваров и его жена - Олимпиада Андреевна Уварова прожили на Карадаге всего несколько месяцев (Слудский, 2004-2005. С. 53).

Карадаг и сегодня, несмотря на всевозможные достижения цивилизации, является своеобразным островком, жизнь на котором требует от человека не только понимания и любви к природе, но и наличия определенных, деловых, моральных, психологических 
качеств, которые А.Ф.Слудский называл «необходимым винтиком», - сколько людей покинули это место из-за отсутствия такого винтика!

Положение с П.П. Уваровым тревожит, поскольку, по всей вероятности, А.Ф. Слудский рассчитывал, что тот сможет руководить хозяйством станции и вместе с В.Н. Вучетичем останется на Карадаге на зимний период. Однако В.Н. Вучетич «решительно заявил, что на зиму один на Карадаге он больше не останется» (Архив РАН. Ф. 311. Оп. 2. Д. 227. Л. 2).

А.Ф. Слудский понимает, что на Карадаге придется остаться ему - другого выбора не существует.

Сбои в работе произошли также у «низшего персонала», который «много неприятностей причиняет» (Там же. Л. 3).

Кажется, что неприятностям нет конца. «Но всего больше те неприятности, - пишет А.Ф. Слудский, - которые в изобилии причиняет О[бщест]во Леденцова [...]». Приводит простой пример о цистерне для сбора питьевой воды: «Вы спрашивали о цистерне - но что можно сделать без денег? Моих сил не хватает, что-бы все время давить и напирать на Общество, и, несмотря на всю мощь и силу участия в делах станции Алексея Петровича - ох как тяжело иметь дело с этим Обществом! Общество тяжело болеет папирократией и бумага совершенно заедает дело» (Там же. Л. 3).

Приводит еще примеры «папирократии»: не выделены небольшие средства для опытов по культивированию лекарственных растений. При этом, ходатайство было послано А.Ф. Слудским заранее, 12 апреля: «6 мая ходатайство было рассмотрено и удовлетворено, о чем меня любезно известили - но денег не прислали до сих пор, - пишет А.Ф. Слудский. - А между тем время посева уже упущено... Наша смета на устройство и оборудование застряла безнадежно, печатанье Трудов - не знаю в каком положении, Иван Алексеевич ничего не пишет, а я здесь на станции исполняю обязанности монтера, слесаря и плотника, Викт[ор] Никол[аевич] - маляра и садовника, оба вместе - библиотекари, делопроизводители и канцелярские служащие...» (Там же Л. 3, 3 об.).

Мы видим, что Общество не может наладить рабочие отношения со станцией. Явно не хватает оперативности в перечислении денег. Срываются плановые работы. Поэтому, А.Ф. Слудский и В.Н. Вучетич не могут привлечь временных рабочих и вынуждены хозяйственные работы выполнять своими силами. Кроме того, необходимо было делать главное - проводить научные исследования. Такое положение дел создавало для работы станции довольно шаткое положение, которое формировало скептическое отношение со стороны А.Ф. Слудского к работе Общества. Необходимо было расширять штаты станции, но для этого у Общества не хватало средств. Только любовь к Карадагу, ответственность за продолжение дела Т.И. Вяземского, могли удержать А.Ф. Слудского на станции.

Вместе с тем, в отношении «папирократии» заметим, что Общество строго соблюдало бюрократические правила своего Устава. Поэтому часто возникали различные издержки, которые, усугубляясь в условиях революционных событий 1917 г., тормозили работу станции.

В завершение письма А.Ф. Слудский пишет: «Итак - ждем Вас! Вода, хотя и не из цистерны, но решительно стала лучше - совсем недурная». Передает приветы А.П. Павлову от себя и жены. Обещает написать письмо А.П. Павлову на днях (Там же. Л. 3 об.).

Кстати, блага цивилизации очень медленно приходили на Карадаг. Так, спустя десятилетия, еще в 1950-е годы питьевую воду на станцию привозили в бочке с помощью лошади, для бытовых нужд собирали дождевую воду и брали из колодцев, а электроэнергию вырабатывала собственная небольшая дизельная установка.

Видимо, в ожидании приезда А.П. и М.В. Павловых, А.Ф. Слудский не стал писать письмо, надеясь на встречу. Но когда надежда была утрачена, отправил письмо, наполненное грустными мыслями. В письме, написанном А.П. Павлову на пишущей машинке (вероятно 
на «Смис Премьер») от 03.07.1917 г. он сообщил: «[...] Ваш приезд вошел в уклад станционной жизни и без Вас здесь пусто...

Пусто в этом году и в смысле количества лиц, работающих на станции: была ботаничка - С.А. Сатина, а сейчас работает зоолог-протозоист А.Г. Алексеев - вот и все приезжие работники текущего сезона. Остальные - а запрашивали очень многие - убоялись и не приехали. И надо сказать убоялись напрасно: и в переживаемые дни Карадаг остается благословенным местом» (Архив РАН. Ф. 48. Оп. 2. Д. 98. Л. 7).

«У нас затишье среди бурного потока слов, - продолжает письмо А.Ф. Слудский, затопивших Россию, затишье, в котором можно собрать мысли и делать дело. Быть может это недостаточно патриотично в трагический момент жизни нашей страны - стоять в стороне от толпы, не пытаясь оказывать непосредственного воздействия на болезненный процесс созревания гражданского сознания, но мне сдается, что правильнее и патриотичнее в настоящее время делать свое дело, не считая числа рабочих часов и не брезгуя никакой черной работой: мне кажется, что как будто опыт показывает достоинство такой тактики, что все хорошие слова, произносимые на митингах ничего не стоят по сравнению с той здоровой атмосферой, которая создается на почве явного деятельного труда и сотрудничества. Этим объясняю я, что у нас на станции идет все сравнительно гладко, что наши служители работают с пяти утра до восьми вечера и при этом и хозяева и рабочие друг другом довольны» (Там же Л. 7, 7 об.).

Заметим, что А.Ф.Слудский был очень трудолюбивым человеком и по времени работал не меньше рабочих. Из текста письма видим, что он наладил рабочие, доверительные отношения с обслуживающим персоналом.

Позиция А.Ф. Слудского к революционным событиям в России, в определенной мере созвучна позиции М.А. Волошина. Поэт, в частности, отметил, что месяцы, последовавшие за февральским переворотом, «[...] были вопиющим и трагическим противоречием между всеобщим ликованием и реальной действительностью. Все дифирамбы в честь свободы и демократии, все митинговые речи и газетные статьи того времени - были нестерпимою ложью. Правда - страшная, но зато подлинная, обнаружилась только после октябрьского переворота. Русская Революция выявила свой настоящий лик, тайно назревавший с первого дня ее, но для всех неожиданный» (Волошин, 1991. С. 315).

Далее в письме А.Ф. Слудский сообщает, что совместно с В.Н. Вучетичем проводит морские исследования по составлению карты распределения глубин, фаций и биоценозов в районе станции. «Кроме того, - пишет А.Ф. Слудский, - мы продолжаем работу по изучению течений. Я вычертил ряд графиков и эти графики впервые начинают давать какие-то смутные контуры некоторых законностей. Работа увлекательная, но не смотря на то, что мы уже сейчас имеем за текущий сезон много больше наблюдений, чем за весь прошлый год тем не менее все это только самые первые шаги в неведомую область. Но надо правду сказать - на научную работу, при всем добром желании, времени, мыслей и сил остается немного. Работы и заботы общехозяйственного порядка и канцелярские дела поглощают почти всю энергию» (Архив РАН. Ф. 48. Оп. 2. Д. 98. Л. 10, 10 об.).

На лодке «Ундина» А.Ф. Слудский и В.Н. Вучетич (рис. 9) проводили наблюдения за морскими прибрежными течениями в 1916-1917 гг., применяя аппарат Экмана. Для того времени это был наиболее совершенный прибор, впервые примененный в Черном море на Карадаге. До настоящего времени приповерхностные и придонные течения, начало изучения которым положено было на станции, исследованы плохо. Подробнее об этом рассказывает работа А.А. Клюкина (Клюкин, 2004. С. 34).

А.Ф. Слудский пишет о соблазнах, которые удаляют от занятий наукой, но позволяют реализовать себя в управленческой деятельности. Так, С.С. Крым предложил ему принять Отузский казенный винный сад «[...] не как заведующему станцией, а просто как некоему гражданину, принять от него, Крыма, этот сад во временное управление, при чем предлагает, что это управление будет мне передано не только по существу, но и официально». В планах 
А.Ф. Слудского появилась цель об объединенной деятельности станции и казенного сада, он планирует «[...] всецело отдаться этой деятельности, при чем, - пишет А.Ф. Слудский, - мне будет предоставлена широкая инициатива в деле использования сада для общегосударственных или местных просветительских целей. Конечно, прежняя цель виноделие отпадает совершенно» (Архив РАН. Ф. 48. Оп. 2. Д. 98. Л. 10 об.-8).

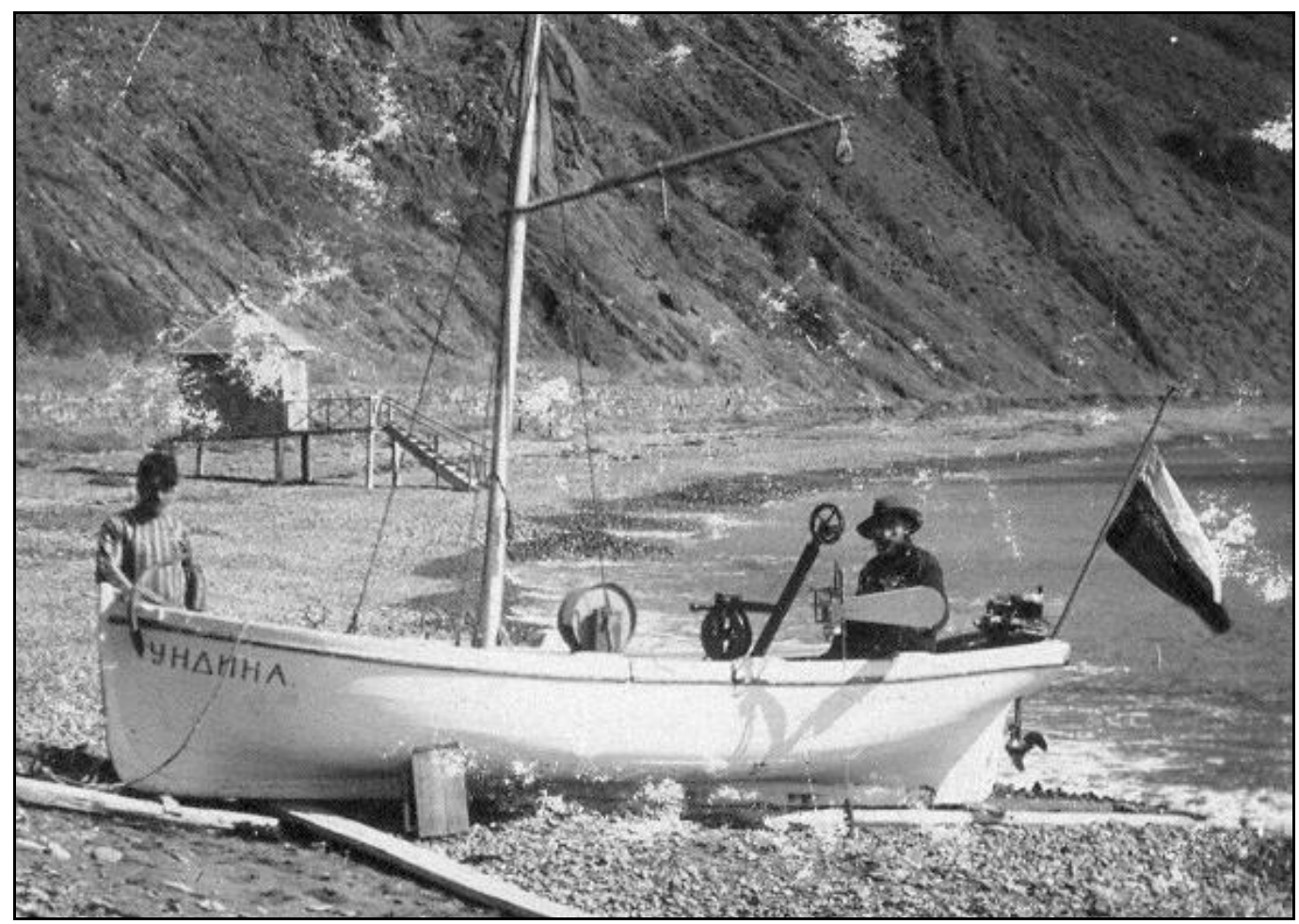

Рис. 9. В.Н. Вучетич в лодке «Ундина» на берегу Карадагской бухты. Фотография 1916-1917 гг. Публикуется впервые. Частный архив А.Ф. Слудского и его семьи в Симферополе.

С.С. Крым, зная административные таланты А.Ф. Слудского, предлагает ему взять сад в свое управление с тем, чтобы он не был убыточным, поскольку виноделие, в связи с введением в России сухого закона, стало проблематичным.

Видимо не раз А.Ф. Слудский советовался с А.П. Павловым о том, где лучше реализовать себя - в Москве, или на Карадаге. «Теперь, - пишет А.Ф. Слудский, - снова поднимается тот-же вопрос: Москва или Карадаг? И душа тянет на Карадаг - здесь я нужнее, здесь больше вложено моей работы и моего умения, здесь больше опасностей для создаваемого детища Терентия Ивановича, которое с таким трудом растет и так еще слабо и хило, что боязно оставить его сиротой ... Опять скажу - как грустно, что Вас нет, что нельзя с Вами посоветоваться» (Там же. Л. 8, 8 об.).

Далее А.Ф. Слудский сообщает А.П. Павлову о неудачах в хозяйственной деятельности П.П. Уварова и его жены, в связи с чем приходится искать выход, поскольку П.П. Уваров «[...] к Карадагу не пришелся и на зиму не останется. Все это осложняет положение и приходится искать выхода» (Там же. Л. 8 об.).

Вновь А.Ф. Слудский сообщает, что Общество «[...] работает, как типичная бюрократическая машина. Бумаги присылают иной раз совершенно нелепые, формализм доводят до крайних пределов, а до всего остального им мало дела». Подчеркивает, что И.А. Каблуков не отвечает ни на письма, ни на телеграммы. Тревожит ситуация с печатаньем Трудов станции. В апреле А.Ф. Слудский послал И.А. Каблукову «[...]последнюю корректуру, и надеялся в мае получить готовый том. Теперь июль - нет ни тома, ни какого-нибудь отклика 
со стороны И[вана] А[лексеевича]. Жив-ли, здоров-ли он?» - задается вопросом А.Ф. Слудский (Там же. Л. 9).

Все же А.Ф. Слудский надеется увидеть А.П. Павлова и М.В. Павлову на Карадаге, «[...]хотя, к сожалению, - подчеркивает он в завершении письма, - мне самому приходится уехать на конец июля и половину августа - чи в Феодосию, чи в Симферополь, сами еще не знаем. Наши сердечные приветы и пожелания здоровья вам обоим. Ваш А[лександр] Слудский» (Там же. Л. 9).

А.Ф. Слудский опасается, что никто из Общества на Карадаг не приедет. Тем самым отодвигается решение вопросов по станции и имению на неопределенный период. Политическая ситуация в стране катастрофически ухудшается. Он обостренно воспринимает данные обстоятельства.

В начале августа супруги находятся в Феодосии. В понедельник, 7 августа 1917 г. А.Ф. Слудский пишет А.П. Павлову письмо, наполненное тревогой за судьбу станции, личными переживаниями, элементами пессимизма: «Приближается осень, а до сих пор у нас на Карадаге грядущее так-же темно и смутно, как судьба всей России». Отмечает, что за три года Бюро Общества так и не удосужилось приехать на Карадаг. «Повидимому теперь, когда общеполитическая атмосфера сгущается до крайних пределов и передвижение затрудняется почти до полной остановки - теперь приедет на Карадаг Бюро Общества!» (Архив РАН. Ф. 48. Оп. 2. Д. 96. Л. 1) (рис. 10).

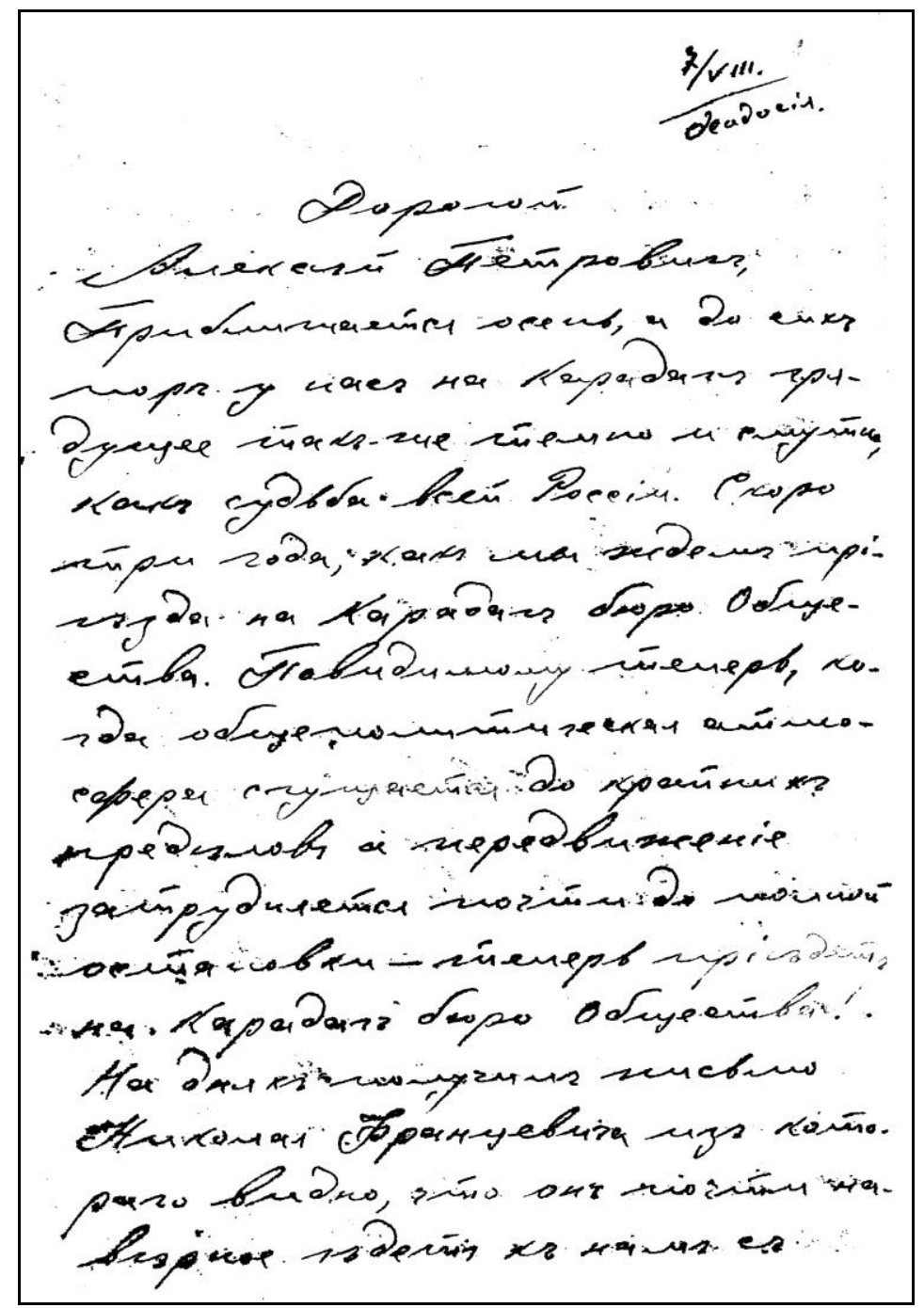

Рис. 10. Первый лист письма А.Ф. Слудского А.П. Павлову от 7.08.1917 г. Копия публикуется впервые. Архив РАН. Ф. 48. Оп. 2. Д. 96. Л. 1. 
А.Ф. Слудский сообщает А.П. Павлову, что получил письмо от Н.Ф. Чарновского, «[...] из которого видно, что он почти наверное едет к нам с семьей в конце августа, а вместе с ним можно ждать и Семена Андреевича. Если-же и на этот раз они не приедут, эмоционально подчеркнул А.Ф. Слудский, - то воистину Карадаг затрещит по всем швам, т[ак] к[ак] я не вижу никакой возможности и просто не имею физических сил продолжать вести это дело при существующей двойственности управления и бухгалтерии и при отсутствии более активной помощи со стороны Общества» (Там же. Л. 1, 1 об.).

Объективно ситуация на Карадаге складывалась так, что станция и имение, как единое целое может работать при непосредственном руководстве А.Ф. Слудского. Второе, неотлаженное управление со стороны Общества, тормозило дело. Главенствующее место в такой ситуации принадлежало А.Ф. Слудскому, способному решать самые разные задачи научные, хозяйственные, административные. Такими талантами ближайшее окружение не обладает. Это понимает и он сам. Так, в письме читаем, что В.Н. Вучетич «[...] решительно настаивает на том, что он на Карадаге остается только при условии, что остаюсь я. Об Уварове говорить нечего - он оказался совершенно неспособен к организаторской и хозяйственной деятельности. И вот мы дотягиваем сезон, внешне все обстоит блестяще, но дальше - несомненная пропасть» (Архив РАН. Ф. 48. Оп. 2. Д. 96. Л. 1 об., 2).

Далее тон письма становится все более мрачным. «При всей моей бесконечной преданности делу Терентия Ивановича, - пишет А.Ф. Слудский, - я не знаю, что мне делать? Мой отъезд теперь грозит тем, что на станции никого и ничего не останется - ничего, вплоть до земли, которую у нас хотел оттяпать Халиль (тот самый!) и который на днях (28 июля) продавал нас с торгов!» (Там же. Л. 2).

Личность Халиля и ситуацию с торгами предстоит выяснить.

Объективные обстоятельства зовут и выпихивают А.Ф. Слудского в Москву. Например, если он оставит университет, то его призовут в армию. Оставаться на Карадаге он не может по материальным соображениям. Как заведующий станцией он получает в месяц 125 рублей, а за пансион необходимо платить 180 рублей с человека. Это же касается и В.Н. Вучетича - его жалованье - 100 рублей в месяц и на его содержании находится старушка мать. «Что-же делать? - пишет А.Ф. Слудский. - Я жду приезда Бюро - и тогда придется решать окончательно, чему быть» (Там же. Л. 2 об.).

Можно только представить себе состояние А.А. Павлова, получившего такие неутешительные вести с Карадага!

Завершая письмо А.Ф. Слудский пишет: «Если, несмотря на все переживаемые ужасы, соберется съезд Ассоциации - а по моему собраться он должен и обязан во имя России - низко кланяюсь Вам Алексей Петрович, быть в случае нужды представителем нашей станции» (Там же. Л. 2 об. 3).

Здесь речь идет об организационном съезде Ассоциации русских естествоиспытателей и врачей, запланированный на август 1917 г., но так и несостоявшийся. В отдельной статье к съезду А.П. Павлов отметил: «Если в мирное время и при нормальных условиях жизни научные исследования, научная организация являются существенными факторами национального прогресса, то теперь и в близком будущем, после пережитых страною потрясений, для ее блага и спасения жизненно необходимо, чтобы и промышленная, и просветительная, и всякая государственная и общественная деятельность во всех соприкасающихся между собою сферах были приведены в стройную, гармоничную взаимную связь и опирались на указания науки» (Цит. по: Варсонофьева, 1947. С. 351).

В статье А.П. Павлов отметил объединяющую силу науки в государственном строительстве. Однако, после октябрьского переворота 1917 г., новая власть явно не опиралась на указания науки.

Вернемся к письму. Завершается оно на пессимистической ноте: «К сожалению Труды наши не распустившись вянут в руках Ивана Алексеевича... Сердечно желаю Вам 
здоровья, крепости и бодрости. Любящий и преданный А[лександр] Слудский» (Архив РАН. Ф. 48. Оп. 2. Д. 96. Л. 3).

Слово Труды - это, и труды самого Т.И. Вяземского, и труды А.П. Павлова, и труды А.Ф. Слудского и В.Н. Вучетича и других людей по становлению научных работ на станции, и неопределенность в первом выпуске Трудов станции.

Справедливо будет указать, что И.А. Каблуков (рис. 11) много предпринял усилий в организации научных работ на станции. В большей мере он отстаивал интересы Общества, в то время, как А.Ф. Слудский - станции. Неудачи в делах станции не могут быть списаны на И.А. Каблукова - здесь межличностный конфликт в различных подходах к делам по управлению станцией иногда доминирует у А.Ф.Слудского над объективными обстоятельствами. В письме отражены кризисные моменты в душе А.Ф. Слудского. В метаниях его настроения, в тревожном воздухе письма, тем не менее, просматривается ответ человека уже избравшего нелегкий путь по сохранению станции - решение остаться на Карадаге. Здесь проявились особенности характера А.Ф. Слудского - объективно показать сложную ситуацию и свое желание уйти от ее решения. Но на самом деле, в данной ситуации, он скрывает, что решил сохранить станцию. В случае отъезда в Москву он сам сталкивает в пропасть станцию! Допустимо ли это? Конечно же нет.

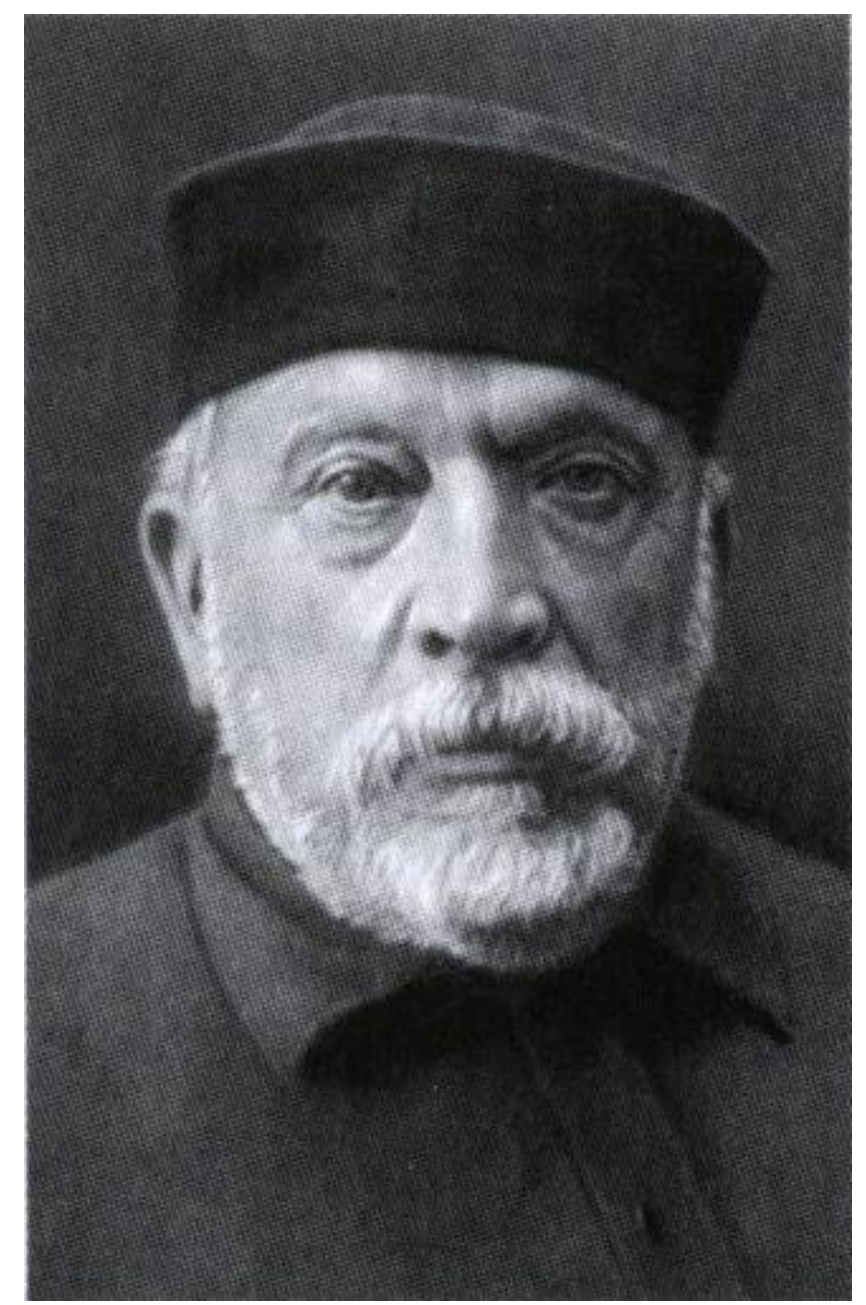

Рис. 11. И.А. Каблуков. Фотография 1920-х гг. (?) (Никс, 2008. С. 133).

На общее содержание письма от 7 августа могло повлиять то обстоятельство, что А.Ф. и Е.Н. Слудские со дня на день ожидали рождение ребенка, волновались. Радостный день наступил уже во вторник, 8 августа, - родилась Александра Александровна Слудская (19171993). 
В общей сложности, в связи с рождением дочери, А.Ф. и Е.Н. Слудские пробыли в Феодосии около месяца. Во время их отсутствия хозяйственные дела на Карадаге вела младшая сестра А.Ф. Слудского - Юлия Федоровна Слудская (Никольская). Вместе с мужем - Пантелеймоном Алексеевичем Никольским и трехлетней дочерью Ангелиной летом 1917 г. они жили в пансионе станции (Слудский, 2004-2005. С. 85).

В честь рождения дочери, осенью 1917 г. А.Ф. Слудский посадил вблизи здания станции сосну. Рядом, в 1921 г. была посажена еще одна сосна - в честь рождения сына Адриана Александровича Слудского (1921-2002). Деревья разрослись и сегодня радуют каждого человека своим величием и тенью в жаркие летние дни. Эти деревья напоминают нам не только о событиях прошлого, но и символизируют прочную связь с Карадагом всей семьи А.Ф. Слудского.

В Москве А.П. Павлов предпринимает меры, направленные на то, чтобы А.Ф. Слудский смог остаться на Карадаге. Так, по всей вероятности, по его просьбе Общество в конце сентября 1917 г. послало ходатайство в Московский университет на имя декана физико-математического факультета о предоставлении ему «[...] научной командировки на Карадагскую станцию на весь учебный год» (ЦИАМ. Ф. 224. ОП. 1. Д. 85. Л. 39). Можно быть уверенным, что такая командировка от университета была предоставлена. Кроме того, была продлена и командировка от Общества. Так же А.П. Павлов ходатайствует перед Обществом о повышении вознаграждения А.Ф. Слудскому и В.Н. Вучетичу. Этот вопрос, как следует из анализа письма А.П. Павлова к Н.Ф. Чарновскому, положительно был решен в конце ноября 1917 г. (Там же. Л. 49, 49 об.).

Третье письмо А.П. Павлову от 9 октября 1917 г. наполнено оптимизмом, в нем звучит благодарность А.П. Павлову за его добрые вести.

Отметим, что письмо А.П. Павлова к А.Ф. Слудскому, посланное, либо переданное им на Карадаг до 9 октября и в котором были изложены эти добрые вести, положившие конец сомнениям А.Ф. Слудского, не обнаружено.

Восторженное начало письма от 9 октября 1917 г.: «Дорогой Алексей Петрович, Ваши добрые вести меня просто потрясли: я так привык за последнее время ко всяким недобрым вестям, что вести добрые звучат для меня как голос с другой планеты. И из всех вестей, конечно, выше и ценнее всех - известие о выходе выпуска Трудов. Вы не можете представить себе, как я боялся за этот выпуск! Я ждал всего худшего: еще весной я слышал в типографии от заведующего типографией, что, вероятно, придется типографию закрыть. Если-бы наш выпуск не вышел, то это был бы такой удар, последствия которого трудно учесть. Поэтому известие о выходе выпуска для меня звучит как самая радостная весть о чудесном спасении близкого человека... Только с этого момента существование станции получает некоторый аргумент, который можно оценивать более высоко или менее высоко, критиковать, даже ругать, но который тем не менее имеет абсолютную ценность, как первый выявившийся результат десятилетних усилий по созданию станции. И я счастлив сейчас за Терентия Ивановича. Это начало его оправдания на суде истории. Нам с вами, верующим в начатое им дело, такого реально ощущаемого оправдания, быть может, и не нужно. Но Вы знаете, сколько было неверующих!» (Архив РАН. Ф. 48. Оп. 2. Д. 98. Л. 4, 4 об.).

В этих словах сконцентрировано главное - станция существует, десятилетние, с начала строительства в 1907 г., усилия по ее созданию не напрасны, станция заявила о себе в научном мире первым выпуском Трудов, идеи Т.И. Вяземского начинали воплощаться в жизнь. Станция стала более известна в научном мире именно по этому, первому выпуску Трудов. Он был издан в 1917 г. в Москве под редакцией И.А. Каблукова и А.Ф. Слудского (Труды Карадагской..., 1917) и сохранился во многих библиотеках бывшего СССР. В литературе о природе Карадага и истории станции, как правило, встречаются ссылки на этот выпуск (рис.12). 
Вып. 1.

Livr. 1.

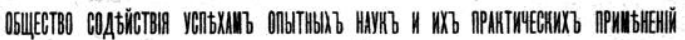
имени Х. С. Леденцова.

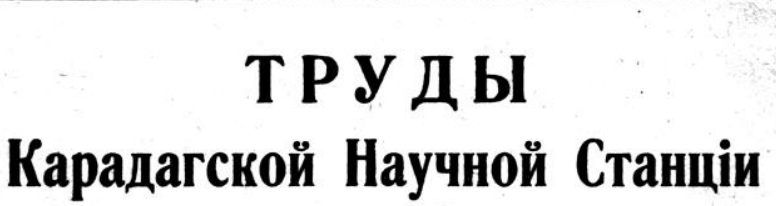

имеНи Т. И. ВЯЗЕМСКАГО.

Выпускъ первый.

Подъ редакціей товар. предс. О-ва засл. проф. И. А. Каблукова и завъдывающаго Станціей А. Ө. Слудскаго.

\section{Travaux de la Station des sciences naturelles \\ à Karadagh (Crimée),} fondée par le $\mathbf{D}^{r} \mathbf{T}$. Wiasemsky.

Rédacteurs: Prof. J. Kablukov et A. Sloudsky.

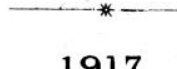

1917.

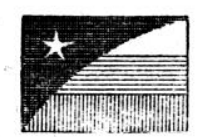

MOCKBA,

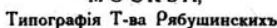

Страстной монаст., Путинковскій пер., собств. цомъ. 1917

Рис. 12. Труды Карадагской научной станции имени

Т.И. Вяземского.- М., 1917. - Вып.1, обложка.

Вернемся к письму А.Ф. Слудского. Он радуется другим добрым вестям. Так, А.П. Павлов выхлопотал ему командировку в Москву с тем, чтобы он мог решить служебные и личные вопросы. «Мне совестно перед Вами и грустно за себя, - пишет А.Ф. Слудский, что я, может быть, был бы нужен Вам в Москве. Но приходится считаться с тем, что у человека две руки, две ноги и одна голова. А оставить Карадаг на зиму без себя при современных обстоятельствах совершенно невозможно: я высоко ценю Вучетича, но ему не дано (и он сам это понимает) той выдержки и хладнокровия, которая необходима сейчас для общего ведения всего дела. Да и работы, надо правду сказать, хватает на всех и все еще остаются залежи дел, которые надо сделать...» (Архив РАН. Ф. 48. Оп. 2. Д. 98. Л. 5).

В этих словах мы видим твердое решение А.Ф. Слудского остаться на Карадаге. Главным в таком решении было желание сохранить станцию и продолжить дело Т.И. Вяземского.

«Третья весть, - продолжает письмо А.Ф.Слудский, - о немедленном принятии Обществом имения - чревата большими последствиями». А.Ф. Слудский имеет в виду положительные последствия. Вновь фигурирует И.А. Каблуков, попрекнувший А.Ф. Слудского в том, что он ведет «[...] по делам станции политику сепаратизма. А мне все кажется, что Общество проникнуто сепаратизмом по отношению к станции и я ничего так не желаю, как фактического, не на словах а на деле, признания со стороны Общества, что 
станция есть неотъемлемая часть Общества. До сих пор Общество точно стыдилось признать нас за свое родное детище. Принятие имения совершенно изменит это отношение, т[ак] к[ак] поневоле заставит ближе подойти к нам и обратить на нас большее внимание» (Там же. Л. 5 , 5 об.).

Далее А.Ф. Слудский благодарит А.П. Павлова за согласие быть редактором второго выпуска Трудов станции. Выпуск вышел в 1918 г. в Феодосии под редакцией А.П. Павлова и А.Ф. Слудского (Труды Карадагской..., 1918) (рис. 13).

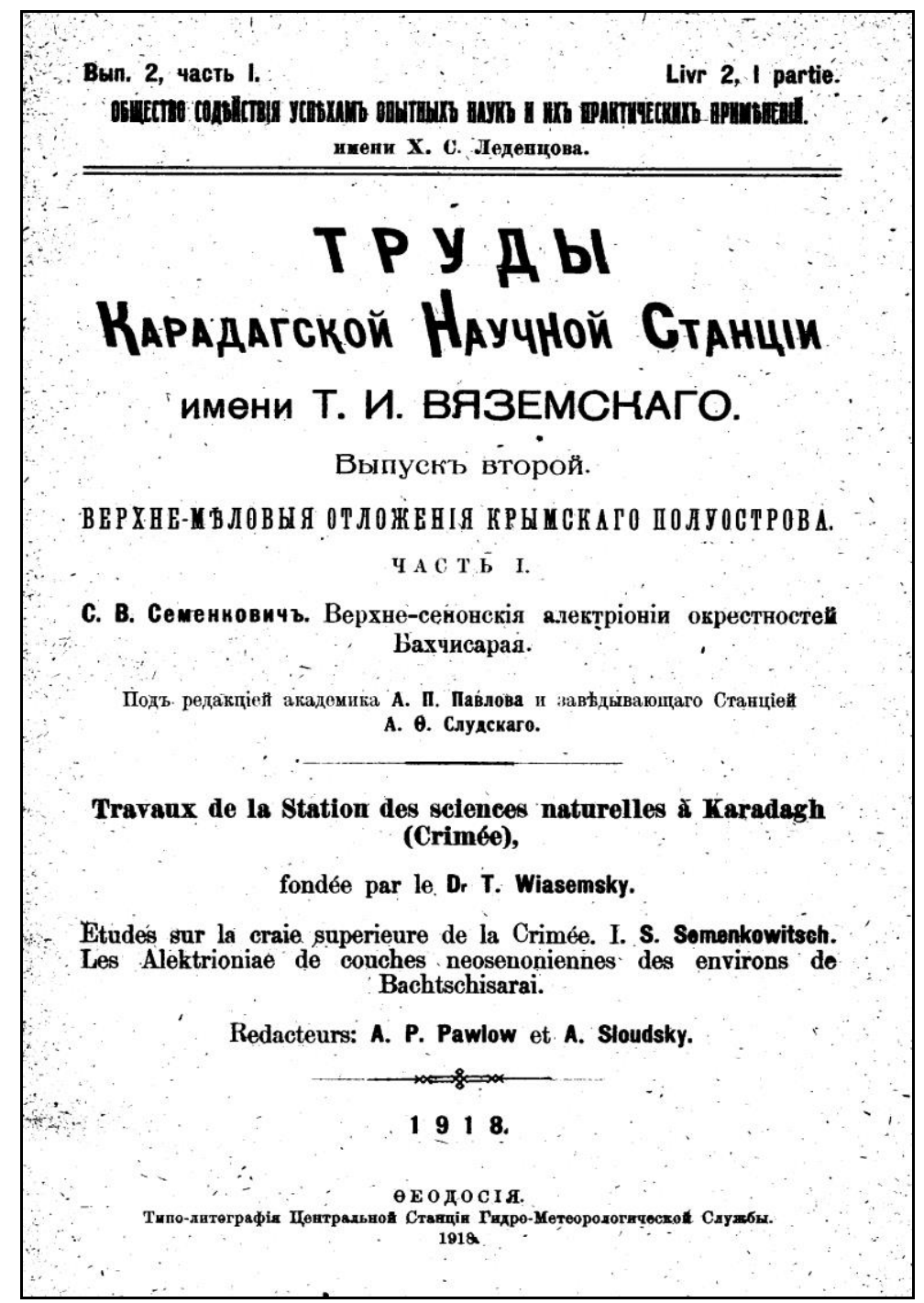

Рис. 13. Труды Карадагской научной станции имени

Т.И. Вяземского.- Феодосия. - Вып. 2. - Ч. 1, титульный лист.

Сообщает о пребывании на Карадаге Н.Ф. Чарновского и его доброжелательном отношении к делам станции: «Очень порадовало нас пребывание на Карадаге Николая Францевича. Его доброжелательное отношение к станции, большой здравый смысл и деловое направление мыслей дают нам надежду видеть в нем очень ценного сотрудника» (Архив РАН. Ф. 48. Оп. 2. Д. 98. Л. 6).

Весьма неблагоприятные события в стране не помешали Н.Ф. Чарновскому приехать на Карадаг в августе 1917 г. Нам неизвестны подробности общения на Карадаге Н.Ф. Чарновского и А.Ф. Слудского. Тем не менее, можно полагать, что Н.Ф. Чарновский, выслушав аргументы А.Ф. Слудского, посоветовал ему остаться на Карадаге. Определенные обещания, данные им по дальнейшей деятельности станции и нормализации отношений с Обществом, вселили у А.Ф.Слудского надежду на будущее. $\mathrm{K}$ сожалению, имя 
Н.Ф. Чарновского - крупного русского ученого, специалиста в области производства и научного менеджмента, было незаслуженно забыто в связи с несправедливым осуждением его по делу Промышленной партии и последовавшим в 1938 г. расстрелом.

Кроме того, заботы А.П. Павлова о благополучии станции, так же вселяли уверенность в продолжении научных работ на Карадаге. Все это оказало положительное влияние на А.Ф. Слудского и сотрудников станции.

В завершении письма А.Ф. Слудский сообщил, что он, его жена и «крошка-девочка» переболели инфлюэнцой [гриппом]. У дочери в результате болезни «[...] сделался внутренний нарыв в бедре, пришлось делать операцию глубокого прореза. Тем временем свалился от инфлюэнцы и я. Но, слава Богу, все налаживается опять по хорошему» (Там же. Л. 6 об.).

Все же А.Ф. Слудский планировал приехать в Москву на некоторое время с тем, чтобы, встретиться с А.П. Павловым, а также уточнить ситуацию по имению, в частности, об изменении условий страхования строений станции. По этому поводу он обращается в Общество в письме от 21 октября 1917 г.: «Я предполагаю выехать в Москву 4-го ноября и, следовательно, если ничто не задержит, буду в Москве 6-го. К этому времени надеюсь подготовить все данные по имению» (ЦИАМ. Ф. 224. Оп. 1. Д. 85. Л. 47).

По всей вероятности, А.Ф. Слудский обговорил с Н.Ф. Чарновским, во время его пребывания на Карадаге, детали передачи станции и имения Обществу. В связи с чем, Общество планировало в присутствии А.Ф. Слудского признать станцию «за свое родное детище». Поездка в Москву не состоялась из-за ухудшения политической обстановки в стране.

В последнем, четвертом письме к А.П. Павлову от 02.11.1917 г. А.Ф. Слудский сообщает: «Давно не писал Вам, в надежде, что скоро лично побываю у Вас и поговорю обо всем, что еще осталось бодрого и отрадного среди общего кошмара в котором мы живем. Но теперь, когда мне надо-бы съездить в Москву, положение так запуталось и обострилось, что я не решаюсь выехать. Я боюсь или застрять в дороге, или застрять в Москве, а это было-бы именно теперь более чем нежелательно» (Архив РАН. Ф. 48. Оп. 2. Д. 98. Л. 12).

В условиях «общего брожения», дошедшего в Крым, А.Ф.Слудский видит себя только на Карадаге: «[...] во всяком случае мое место при каких бы то ни было “исторических событиях" как теперь называют всякое безобразие - на Карадаге. Вот почему я так неохотно думаю о возможности застрять в Москве! Итак, что будет дальше - увидим, а пока воспользуемся тем высоким благом культуры, которое у нас еще осталось - почтою. Имеются текущие дела относительно которых хотелось бы с Вами поговорить и узнать Ваше мнение. Начну с важнейшего» (Там же. Л. 12 об.).

К важнейшему делу А.Ф. Слудский относит появление на Карадаге в начале октября известного ученого, энтомолога Владимира Афанасьевича Караваева (1864-1939). Он весьма подробно пишет о нем. Указывает, что В.А. Караваев не только известный ученый и путешественник, но и крупный помещик Киевской губернии. В своем имении он создал энтомологическую лабораторию. Опасаясь разгрома имения, планировал перевезти коллекции в Крым. Заочно купил участок земли в районе Отуз, чтобы построить помещение для своих коллекций. «Но, как водится, - пишет А.Ф. Слудский, - его надули: земля оказалась в каком-то неприступном месте и он от нее отказался. Но решил остаться поискать, не найдет-ли чего подходящего, и, зная о существовании станции, пришел к нам в надежде найти приют и помощь.

Карадаг его, видимо, очаровал» (Там же. Л. 16, 16 об.).

А.Ф. Слудский предложил В.А. Караваеву «[...] войти в той или иной форме в соглашение с Леденцовским Обществом. За эту мысль Караваев ухватился [...]» (Там же. Л. 16,16 об.). Оба разработали схему обращения в Общество, в которой, в частности, указано, что В.А. Караваев устраивает на станции энтомологическую лабораторию. Общество предоставляет ему в пожизненное пользование участок земли, на котором он возводит жилой 
дом. Все расходы по строительству дома, устройству лаборатории он принимает на себя. Так же А.Ф. Слудский послал письмо Н.Ф. Чарновскому, с просьбой поговорить о В.А. Караваеве с С.А. Федоровым. Пишет, что Н.Ф. Чарновский ответил ему: «[...] при надлежащей разработке соглашения, предложение г[осподина] Караваева не встретит возражений. Лично я, и Семен Андреевич также, признали его принципиально весьма приемлемым» (Там же. Л. 13, 13 об.). Желая знать мнение А.П. Павлова, он сообщает: «Вот, Алексей Петрович, то дело, которое я считаю сейчас наиболее важным. Мне чувствуется, что в лице Караваева станция может приобрести очень ценного сотрудника и что его дела для станции могут, в случае соответствующей почвы, пойти и гораздо дальше его обещаний в официальном предложении [...] я желал - бы знать Ваше мнение, т[ак] к[ак] думаю и считаю, что оно наиболее важно для всего дела» (Там же. Л. 14).

Карадагская станция, действительно, приобрела в лице выдающегося энтомолога В.А. Караваева нужного и ценного сотрудника. К работе на станции он приступил в 1918 г., но проработал недолго, уже весной 1919 г. уехал в Киев и в июне начал работать в Зоологическом музее Академии наук Украины. Вся дальнейшая работа была связана у него с музеем, куда он и поместил свои богатые зоологические коллекции (Парамонов, 1939). Привлечение известных, крупных ученых для постоянной работы на Карадаге, является актуальным и в наше время.

Второе дело так же важно. А.Ф. Слудский советуется с А.П. Павловым по поводу продажи коктебельского участка земли, принадлежавшего станции. Сообщает, что есть покупатель, готовый за 40000 наличными его купить. Отмечает, что «С.С. Крым советует продавать». А.Ф. Слудский готов продать этот участок, чтобы выплатить Обществу все долги Т.И. Вяземского. В Обществе время от времени возникают разговоры об этих долгах, о которых часто напоминает И.А. Каблуков. Его позиция, как пишет А.Ф. Слудский, следующая: «[...] станция существует милостию Общества, которое получило станцию не бесплатно, а выплатило долги Терентия Ивановича». Далее А.Ф. Слудский пишет об одном из заседаний Бюро, «[...] на котором Ив[ан] Ал[ексеевич] довольно цинично - по крайней мере на мою мерку - высчитывал сумму этих долгов - все это заставляет меня очень желать уплатить Обществу все долги Терентия Ивановича, ликвидируя фактически ненужный станции участок, и тем навсегда уничтожить почву для неуместных по отношению к памяти Терентия Ивановича разговоров. Быть может было-бы возможным произвести операцию этой продажи с достаточной осторожностью, что бы не повредить основной мысли о необходимой охране Карадагского имения? А может быть все те органы, у которых мы просим охраны, только фикция?» (Там же. Л. 15, 15 об.).

Отметим, что долги Т.И. Вяземского определенным грузом легли и на Общество, и на душеприказчиков. Конечно, в данном случае А.Ф. Слудский отстаивает в первую очередь моральную и фактическую сторону дела, поскольку стоимость имения, станции и библиотеки - значительно превышали долги. Но, как видим, была и другая, «циничная» точка зрения. Впрочем, к денежным вопросам всегда следует относиться с большой долей осторожности, поскольку они, как правило, у причастных к ним людей вызывают споры, где каждая сторона считает себя правой.

А.Ф. Слудский хочет как можно скорее закрыть вопросы, связанные с долгами. Ради этого и предлагает положительно решить вопрос о продаже участка. Он знает, что А.П. Павлов против продажи этого участка и просит его подробнее изложить свои мотивы: «Я очень жалею, что не знаю в точности Вашей мотивировки относительно нежелательности продажи и был бы Вам от души благодарен, если бы Вы сочли возможным хотя вкратце сообщить мне» (Там же. Л. 15 об.).

В письме речь идет об участке, расположенном в удалении от станции, в береговой зоне у подножия хребта Кок-Кая, недалеко от населенного пункта Коктебель. Можно понять А.П. Павлова, видимо, не желавшего терять живописную, имеющую научно-познавательную ценность территорию. 
Была ли охрана Карадагского имения фикцией? - предстоит выяснить. Интересно отметить, что само географическое, «островное» положение имения, удаленного от населенных пунктов, способствовало А.Ф. Слудскому в сохранении станции в разрушительные 1917-1922 гг.

«Письмо настолько затянулось, - в завершении пишет А.Ф. Слудский, - что приходится кончать его, что бы не задерживать отсылкой, хотя еще далеко не все написано, о чем я хотел Вам написать. Оставляю до другого раза. Марии Васильевне сердечный привет от всех нас. Доброго здоровья! Ваш А[лександр] Слудский» (Там же. Л. 15 об.).

По всей видимости, на этом переписка с А.П. Павловым временно прервалась. Почтовая связь с Москвой становилась весьма затруднительной и периодически прекращалась - это «высокое благо культуры» постепенно уходило в небытие.

В конце 1917 г. А.Ф. Слудский написал небольшой отчет за год, в нем - итог о научной и хозяйственной деятельности станции: «1917 год был весьма тяжелым годом для деятельности станции: в связи с общей экономической разрухой, вызванной войной и событиями внутренней жизни страны, положение станции к концу 1917-го года стало весьма тревожным. Работа станции, как научная, так и по продолжению оборудования затруднялась все более и более и к концу года должна была сократиться до крайних пределов. Обесценение денег, затрудненность сношений станции с Обществом имени Х.С. Леденцова, крайне тяжелое положение самого Общества после ноябрьского переворота в Москве, растущая анархия в стране и искусственно раздуваемая национальная рознь среди разноплеменного населения Крыма - таковы те общие условия, в которые попала станция к концу года. Эти условия слишком неблагоприятны для продуктивной научной работы, и вся энергия направляется на то, что-бы сохранить станцию до более благоприятного времени» (Архив КБС. Оп. 1. Д. 2. Л. 1).

А.Ф. Слудский указывает на работы по устройству и оборудованию станции. Перечислим некоторые: заложен опытно-показательный плодовый садик, продолжены работы по устройству декоративного садика, построена балюстрада перед домом, начаты работы по восстановлению запущенных виноградников, домик на берегу приспособлен под баню, сделаны полки для книг и положено начало карточному каталогу библиотеки. Так же Н.Ф. Чарновским «произведены изыскания для водоснабжения станции и имения» (Там же. Л. 1).

Заметим, что на протяжении десятилетий взрослые деревья плодового сада, заложенного В.Н. Вучетичем, радовали взор каждого посетителя станции. К сожалению, в 1970-х гг. при строительстве здания дельфинария, мешавшие строительству деревья, были уничтожены под корень. Приблизительно в это же время изящная балюстрада, была заменена на безликое современное ограждение. Ранее, в середине 1960-х гг., все старые виноградники были уничтожены - частично их место занимают сейчас несколько жилых домов.

Вернемся к отчету. А.Ф. Слудский пишет, что в фонды библиотеки, в результате пожертвований и в обмен, от различных организаций и частных лиц поступило 238 наименований книг. Так же было закуплено 38 наименований книг и журналов (Там же. Л. 1 об.).

Пишет о ходатайстве В.А. Караваева в Общество о предоставлении ему одной из комнат станции для обустройства в ней энтомологической лаборатории, заведывание которой принадлежит ему пожизненно, а также участка земли около 900 квадратных саженей с тем, чтобы выстроить жилой дом, который остается в его пожизненном пользовании. «Совет Общества Леденцова, - пишет А.Ф. Слудский, - рассмотревши означенное предложение постановил принять его» (Там же. Л. 1 об., 2).

Из отчета узнаем о кончине заведующего Центральной гидрометеорологической станцией Черного и Азовского морей инженера Михаила Николаевича Сарандинаки (18741917), неоднократно оказывавшем содействие в работе станции. А.Ф. Слудский пишет, что 
«1 ноября [...] был убит большевиками в Москве Сергей Владимирович Семенкович, взявший на себя обработку принадлежащей станции коллекции верхнемеловых ископаемых Крыма» (Там же. Л. 2). Подробности о С.В. Семенковиче (1892-1917) изложены в публикации Ж.К. Владимировой и Е.И. Владимирова (Владимирова, Владимиров, 2008. С. 31-37).

«Научная работа станции, - пишет А.Ф. Слудский, - протекала в отчетном году крайне неровно и отрывочно. Персонал станции, заваленный административной и хозяйственной работой, не мог работать достаточно планомерно, а приезжие силы почти не посещали станции в виду общей неустойчивости положения России и затрудненности передвижений» (Архив КБС. Оп. 1. Д. 2. Л. 2). Пишет о себе, что проводил геологические исследования: «[...] продолжал сбор материала по геологии и палеонтологии Карадага. Совместно с В.Н. Вучетичем продолжал работу по исследованию морских течений в ближайшем к станции районе» (Там же. Л. 2). Пишет о энтомологических исследованиях В.Н. Вучетича. Дает интересные сведения о том, что Николай Федорович Чурин (1884-?) «производил исследования имеющихся на Карадаге жил агата. Им было доставлено в Москву около 10 пудов этого минерала. По испытаниям произведенным на Петергофской гранильной мастерской Карадагский агат оказался пригодным лишь для мелких поделок, но не для ступок» (Там же. Л. 2 об.).

Из приезжих специалистов на станции, кроме минералога Н.Ф. Чурина работали зоолог А.Г. Алексеев (отчет о работе не представил) и ботаник Софья Александровна Сатина (1879-1975). Она «[...] работала на станции с 24 мая по 24 июня и изучала местную грибную флору. В течение этого времени ею было собрано около 200 видов грибов» (Там же. Л. 2 об.).

Кратко расскажем о С.А. Сатиной - известном ученом, ботанике-генетике. Это двоюродная сестра композитора Сергея Васильевича Рахманинова (1873-1943). Написала воспоминания о своем брате. В 1921 г. эмигрировала в Германию, а затем в США, где работала в отделе генетики института Карнеги, затем в экспериментальной генетической станции при Смит колледже (Российское научное..., 2011. С. 541).

Несмотря на неблагоприятные события 1917 г., не позволившие станции широко развернуть научные исследования, А.Ф. Слудский и другие сотрудники вступали в 1918 г. с верой в счастливую судьбу науки на Карадаге, не ведая о том, что впереди грядут еще более тяжелые, в сравнении с 1917 г., испытания.

\section{Заключение}

А.Ф. Слудский, в условиях революционных событий 1917 г. решил остаться на Карадаге ради сохранения станции. В письмах к А.П. Павлову и М.В. Павловой находим формирование меры ответственности перед идеей Т.И. Вяземского, перед обществом, а прежде всего перед собой, позволившей сохранить станцию, сохранить научное знание на Карадаге.

Объективно обстоятельства складывались так, что ни Общество, ни сотрудники станции не смогли бы уберечь станцию от разграбления и разрушения. Вряд ли смог бы сохранить станцию С.С. Крым. Это удалось сделать заведующему станцией А.Ф. Слудскому. По образному выражению C.C. Крыма, суть его личности состояла в том, что он - «Nubes collectas repugnat solemque reducit» [Набежавшие облака разгоняет и солнце вновь выводит (лат.)] (Крым, 1917. С. 15). Главным научным событием в истории станции стал выход первого выпуска Трудов Карадагской научной станции имени Т.И. Вяземского. Этим знаменательным событием завершился десятилетний (1907-1917) период становления станции.

Станция (рис. 14) прошла сложный, противоречивый, тернистый путь развития. В истории станции были и будут радостные и печальные события: в той или иной мере все они 
связаны с памятным 1917 г., когда усилиями одной личности станции была обеспечена сохранность. Такой личностью в критический период истории станции (1917-1922) стал А.Ф. Слудский. О положении станции в 1918-1922 гг. расскажем в отдельной статье.

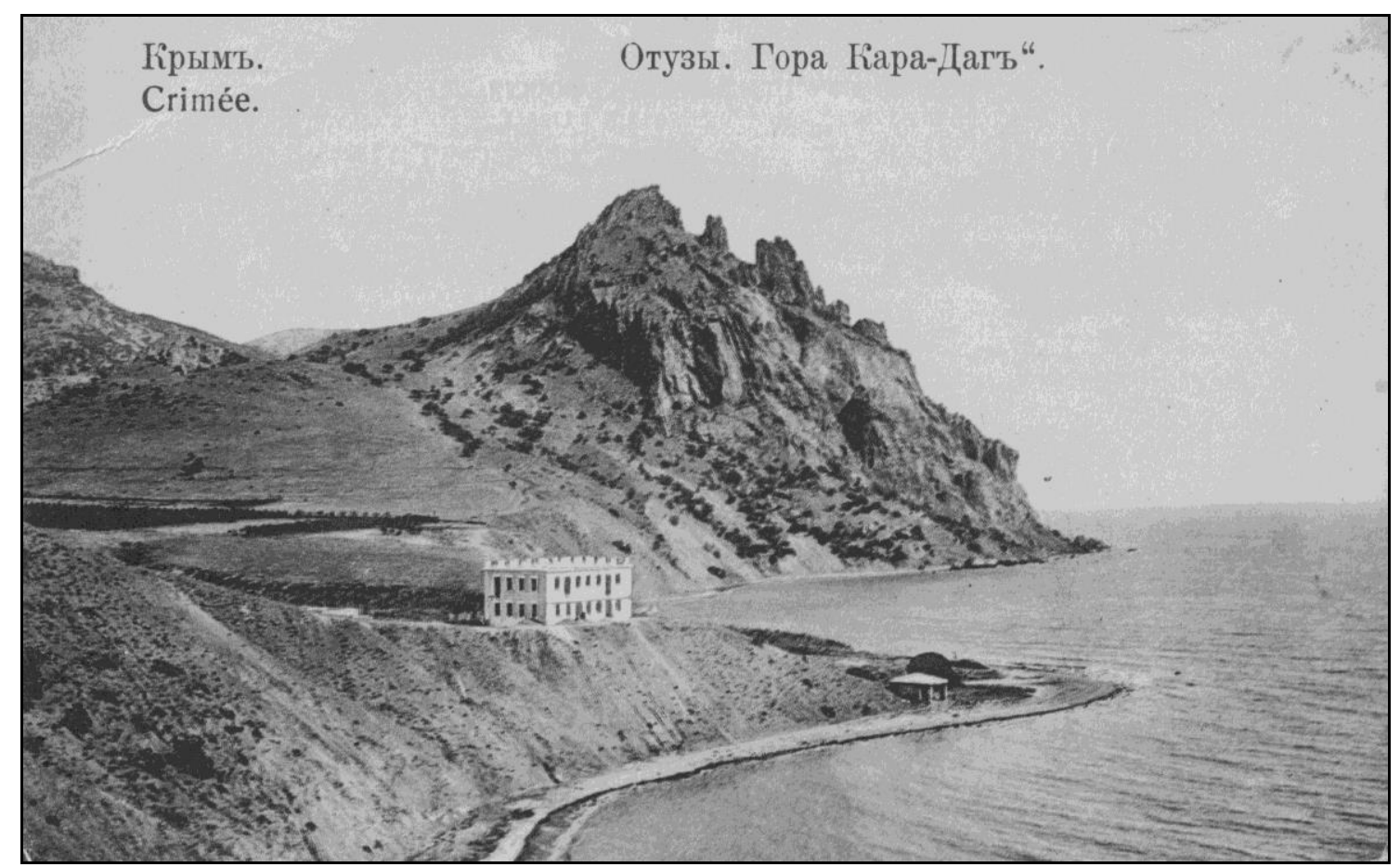

Рис. 14. Карадагская научная станция. Почтовая карточка 1911-1912 гг.

А.Ф. Слудский хорошо знал и любил весь Крым. Известные крымские ученые В.Г. Ена и Н.И. Лысенко, во время обучения в Симферопольском педагогическом институте, слушали лекции А.Ф. Слудского. В память о своем учителе в 1986 г. они назвали одну из скалистых вершин горного Крыма его именем (Ена, Лысенко, 1986. С. 3). Вершина Слудского, высотой 550 м., находится на северном макросклоне Главной Крымской гряды и хорошо видна из Байдарской долины (Ена и др., 2011. С. 181).

Приношу благодарность наследникам А.Ф. Слудского и хранителям его семейного архива в Симферополе - Алексею Николаевичу и Елене Абрамовне Оноприенко за предоставленную возможность работать с материалами этого архива.

Выражаю признательность научному сотруднику Архива РАН Наталье Викторовне Литвиной за методическую помощь в написании статьи.

Благодарю дирекцию и сотрудников ЦИАМ за помощь при работе в архиве.

Выражаю благодарность Петру Григорьевичу Семенькову, директору Карадагского филиала ИнБЮМ в 1989-1997 гг., за оказанное содействие в работе с материалами архива Карадагской биологической станции.

\section{Список литературы}

1. Бачинский А.И. Николай Алексеевич Умов // Временник Общества содействия успехам опытных наук и их практических применений им. Х.С. Леденцова, состоящего при императорском Московском университете и императорском Московском техническом училище. - М., 1915. - Вып. 1. - С. 1-32.

2. Варсанофьева В.А. Алексей Петрович Павлов и его роль в развитии геологии / Второе исправленное и дополненное издание. - М.: МОИП, 1947. - 375 с. 
3. Владимирова Ж.К., Владимиров Е.И. Неизвестные страницы из истории Карадагской научной станции. От 90-летнего юбилея - к 100-летию // Культура народов Причерноморья, 2008. - № 131. - С. 7-38.

4. Волошин М.А. Россия распятая / Стихотворения. Статьи. Воспоминания современников / Вступ. ст. З.Д. Давыдова, В.П. Купченко; Ил. Н.Г. Песковой. - М.: Правда, 1991. - С. 309-328.

5. Ена В.Г., Ена Ал.В., Ена Ан.В. Краткий географический словарь Крыма. - Симферополь: Бизнес-Информ, 2011. - 264 с.

6. Ена В.Г., Лысенко Н.И. Вершина его имени // Советский Крым. 1986. - 14.10. - № 199 (12644). - С. 3.

7. Клюкин А.А. Исследователь Карадага (к 120-летию А.Ф. Слудского) / Карадаг. История, геология, ботаника, зоология: Сб. научн. тр., посвященный 90-летию Карадагской научной станции им. Т.И. Вяземского и 25-летию Карадагского природного заповедника НАН Украины. Книга 1-я. - Симферополь: Сонат, 2004. - С. 28-37.

8. Крым С.С. Терентий Иванович Вяземский. Встречи и воспоминания // Труды Карадагской научной станции имени Т.И. Вяземского / Под ред. И.А. Каблукова и А.Ф. Слудского. - М.: Тип. Т-ва Рябушинских, 1917. - Вып. 1. - С. 12-17.

9. Медушевская О.М. Теоретические проблемы источниковедения. М., 1976. - 125 с.

10. Михаленок Д.К. К истории Карадагской научной станции им. Т.И. Вяземского (по материалам архива РАН) / Фундаментальная наука: проблемы изучения, сохранения и реставрации документального наследия: Материалы Международной научной конференции / Отв. ред. В.Ю. Афиниани. - М.: Архив РАН, 2013. - С. 403-409.

11. Михаленок Д.К., Лапченко В.Ю. Книги В.Н. Вучетича в библиотеке Карадагского природного заповедника Национальной Академии наук Украины // XIV Таврические научные чтения (31 мая 2013 г., Симферополь): сборник научных статей. Часть 2 / гл. ред. Е.Б. Вишневская. - Симферополь: КРУ «Центральный музей Тавриды», 2014. - С. $11-15$.

12. Никс Н.Н. Московская профессура во второй половине XIX - начале XX века. Социокультурный аспект. - М.: Новый хронограф, 2008. - 304 с.

13. Павловская геологическая школа / [И.А. Стародубцева, 3.А. Бессуднова, С.К. Пухонто и др., отв. ред. Ю.Я. Соловьев]. - М.: Наука, 2004. - 211 с.

14. Парамонов С.Я. В.О. Караваєв // Збірник праць зоологічного музею,1941. - № 24. - С. 3 8.

15. Российское научное зарубежье: Биоблиографический справочник / Гл. ред. Ю.В. Мухачев, ред.-сост. М.Ю. Сорокина; Под общ. ред. Г.А. Месяца и Е.П. Челышева. - М.: Парад, 2011. - 716 с.

16. Слудский Е.А. Карадаг. Воспоминания (1917-1926 гг.). - Симферополь: СОНАТ, 20042005. - 112 c.

17. Труды Карадагской научной станции имени Т.И. Вяземского / Под ред. И.А. Каблукова и А.Ф. Слудского. - М.: Тип. Т-ва Рябушинских, 1917. - Вып. 1. - 113 с.

18. Труды Карадагской научной станции имени Т.И. Вяземского / Под ред. А.П. Павлова и А.Ф. Слудского - Феодосия: Типо-литография центральной станции гидрометеорологической службы, 1918. - Вып. 2. - Ч. 1. - [2], 26 с.

\section{Архивные материалы}

1. Архив Карадагской биологической станции при ФГБУН «Карадагская научная станция им. Т.И. Вяземского - природный заповедник РАН». (Далее: Архив КБС). Оп. 1. Д. 2.

2. Архив КБС. Оп.1. Д. 25.

3. Архив Российской академии наук. (Далее: Архив РАН). Ф. 48 (А.П. Павлов). Оп. 2. Д. 96.

4. Архив РАН. Ф. 48. Оп. 2. Д. 98. 
5. Архив РАН. Ф. 311 (М.В. Павлова). Оп. 2. Д. 3.

6. Центральный исторический архив Москвы. (Далее: ЦИАМ). Ф. 224 (Общество содействия успехам опытных наук и их практических применений имени Х.С. Леденцова, состоящее при императорском Московском университете и императорском Московском техническом училище). Оп. 1. Д. 66.

7. ЦИАМ. Ф. 224. ОП. 1. Д. 85.

8. Частный архив А.Ф. Слудского и его семьи в Симферополе. (Далее: ЧАСС). (Архив не систематизирован). Е.Н. Слудская. Заметки о семье Слудских.

9. ЧАСС. Тетрадь стихов А.Ф. Слудского. Стихотворение «Осенние дни».

Поступила 21 июля 2016 г. В окончательном виде 29 августа 2016 г.

\section{A.F. SLUDSKY AND THE T.I. VYASEMSKY KARADAG SCIENTIFIC STATION IN 1917 D.K. Mikhalenok \\ Feodosia, Russian Federation,dmikhalenok@gmail.com}

In 1917 due to well-known political events in Russia the work of T.I. Vyazemsky Karadag Scientific Station was seriously endangered. Nevertheless, the scientific research was being carried by efforts of a few guest scientists, as well as A.F. Sludsky, the Chief of the station, and his assistant V.N. Vuchetich. The first edition of Proceedings of the Karadag Scientific Station was issued, which made it possible for the world scientific community to learn about the Station. However, under the pressure of critical social conditions A.F. Sludsky had to decide between Moscow and Karadag. For the purpose of saving the Station, he chose to stay at the Karadag. The motives of such a complicated decision are described in his letters to A.P. Pavlov. Archival data analysis reveals new pages of the history of the Karadag Scientific Station.

Key words: T.I. Vyazemsky Karadag Scientific Station, Kh.S. Ledentsov Society, year 1917 events, scientific research at the Karadag, saving of the station 